\title{
Architecture as Ornament: Louis Sullivan's Late Work
}

\author{
By Michael O'Brien*
}

\begin{abstract}
It would be hard to assert that one can understand an entire building by looking at a part so small as a piece of ornament, but after constructing through drawing, a number of these pieces of ornament, and doing the same for Sullivan's late commissions, I believe that it can now be asserted that Sullivan was designing buildings that were architectural ornament at a large scale. Sullivan's belief in his own creative will, fueled by the power of nature, learned from the lectures of Asa Grey, the poetry of Whitman, the drama of Richard Wagner's music Nietzsche's "Übermensch," Goethe's "Urpflanze" and his utopian ideal of Chicago seems to have been the key to the visceral power of his architectural ornamental that can only be described as fantastic and a career achievement. But Sullivan went farther than the design of ornament according to the formal methods documented his last publication, "A System of Architectural Ornament according to Man's Powers." Most of his last series of architectural commissions show evidence that he was attempting to construct whole buildings according to the same formal methods used in making the ornament. This paper will present an overview of Sullivan's principles of ornament and the primary ornament types he employed across his fifty-year career, and will focus on the medallion type of ornament and its role in the development of Sullivan's commissions following his break from Dankmar Adler in 1895 and its pivotal role during his last period of practice, 1907- 1919 in transforming inert buildings into vibrant containers of human energy.
\end{abstract}

\section{Introduction}

The role of nature in architectural ornament has been actively questioned since architectural surfaces were used by Egyptians to record history. If we accept Alois Riegl's analysis, the change from accurate depiction to artistic interpretation of botanical species occurred as early as the Egyptian Middle Kingdom, 2040 B.C. Riegl bases this assertion on the presence of droplet-elements added to the historically recognized volute-calyx form of the Lotus ornament. He proposes that the droplet additions are an artistic rather than representational response to a judgement made by the artist that the filling the space was more important than accurately representing the Lotus. ${ }^{1}$

Gottfried Semper had offered material as the underlying driver of ornamental form which Riegl countered with an example (of several materialist refutations) of a prow ornament from a Maori canoe. The paired spiral ornament was produced using the chip-carving method, making the form and method not "natural" to each

\footnotetext{
"Professor, Texas A\&M University, USA.

1. A. Riegl, The Problems of Style: Foundations for a History of Ornament (ed.) David Castriota (Princeton, NJ: Princeton University Press, 1993), 65.
} 
other in wood. $^{2}$ In place of material and technique, Riegl proposes that the will and ingenuity of the artist drives the adaptation of natural forms to the specific design context in order to construct ornamental form solving the visual problems of field filling and asymmetry while maintaining visual unity.

The premise of the artist as the origin for form in ornamental design is implicit in the title of Sullivan's 1924 publication "A System of Architectural Ornament According with a Philosophy of Man's Powers". In Sullivan's view, "Man's Powers" were the ability to perceive and transform the inorganic into the organic, to sympathize, to "enter into communion with living and lifeless things." To see stone, iron or clay transformed into organic form was the same as seeing the building transformed into a living organism for Sullivan, and his ornament was the key to presenting this organism to all who entered.

"A System of Architectural Ornament According with a Philosophy of Man's Powers" was Sullivan's only graphic essay explaining the principles and processes, underlying what is held by many in architecture and material culture to be the most significant development in architectural ornament ever achieved. "A System" is Sullivan's only written instruction for how to transform lifeless matter into forms of life. In "A System" Sullivan suggests only two references to the reader, "Gray's School and Field Book of Botany" (1857) by Asa Gray and Edmund Wilson's (1896) "The Cell in Development and Heredity". Sullivan cites Asa Gray in the context of his education in Moses Woolson's classes at the English high school. In "The Autobiography of an Idea" Sullivan recalls "After recess came nature study with open book. Chief among them Gray's 'School and Field Book of Botany' Louis's playground; then came a closing lecture by the Master."

Sullivan continues, "It was in the nature studies, and in these closing lectures, particularly those in which he dwelt upon the great out-of-doors, and upon the glories of English literature, that the deep enthusiasms of the man's nature came forth undisguised and unrestrained, rising often to the heights of impassioned eloquence, and beauteous awakening imagery. In a sense, Moses Woolson's school room partook of the nature of a university - quite impressively so when Professor Asa Gray of Harvard came occasionally to talk botany to the boys."

Moses Woolson and Asa Gray are two of the three teachers Sullivan mentions favorably in "An Autobiography." Clearly these teachers were instrumental in engaging Sullivan's intuitive love of nature. This paper proposes Asa Gray's textbook "Gray's School and Field Book of Botany," published in 1857, was an enduring source of insight and artistic inspiration for Sullivan, extending deep into Sullivan's career and directly informing his medallion type ornament.

Gray was a professor of natural history at Harvard from 1842 to 1873 and the leading American Botanist. His life work, "The Flora of North America" was published in 1838. Gray was one of the leading American advocates for Darwin's

2. M. R. Olin, Forms of Representation in Alois Riegl's Theory of Art (Penn State University Press, 1992), 68-69.

3. L. Sullivan, A System of Architectural Ornament according with a Philosophy of Man's Powers (New York: Eakins Press, 1967), 2.

4. Sullivan, The Autobiography of an Idea (New York: Dover Publications, 1956), 165.

5. Ibid, 166. 
theory of natural selection, and is credited with doing more to unify North American taxonometric knowledge than any other naturalist. ${ }^{6}$

"Gray's School and Field Book of Botany" is an introductory text on the subject of Botany and is structured as a series of thirty-four lessons. The lessons proceed from the general context of Botany within the larger field of Natural History, through basic growth stages of plants from seeds to buds, branches and into the morphology of roots, and leaves. Unlike the representational basis of books like Ruprich-Roberts and Owen Jones, Gray's Botany sought to present the inner structures and inner workings of plants, from rootlet to sepal, not simply appearances but analysis of stages of growth, associated structure and reproduction. Gray's book is simply illustrated with line-art engravings of both pictorial and analytical diagrams pertaining to the subject under discussion. This relative simplicity is appropriate to the clinical approach to flora and stands in contrast to the stylized fully-rendered illustrations in other publications thought to be critical sources for Sullivan's ornament such as "Flore Ornamentale" by Victor RuprichRobert, or "The Grammar of Ornament" by Owen Jones. By comparison, the other text referenced by Sullivan in "A System", Edmund Wilson's book, has few illustrations and is written for the advanced student of cellular biology and genetics.

One wonders what Sullivan saw in these books. Asa Gray's book would have been a long-standing companion, familiar since his attendance at English High School. This familiarity makes Gray's book a more likely influence for Sullivan during the formation of his thoughts and execution of major commissions than Wilson's book (1896), which wouldn't be published for another thirty-nine years. Though Wilson's lectures, the basis for his book, were first publicly presented in 1892, his books 1896 publication date places it after the Auditorium, Stock Exchange, Wainwright and Guaranty buildings were completed. This publication date rules out "The Cell in Development and Heredity" as a key source for the origin of Sullivan's ornament, leaving it perhaps as an affirmation of the interrelationship between inorganic, geometric forms with strict axis and perimeter rules, and the organic, which during cell division become geometric. Perhaps this is what Sullivan is alluding to when he writes on Plate 5 of "A System", "The Advanced Student who wishes to investigate the power that antedates the seedgerm (which in reality is a sort of embryo) is referred to that remarkable work by Professor Wilson "The Cell in Development and Heredity"."

\section{Sullivan's Ornamental Form Types}

Sullivan employed a limited set of ornamental forms across his almost-fifty years of practice. This can be attributed largely to the limited number of locational conditions presented by design and building practices between 1883 and 1924 . These conditions are generally described as:

6. A. H. Dupree, Asa Gray 1810-1888 (Cambridge, MA: Harvard University Press, 1959), 386. 
- The incremental articulation of a line.

- Punctuation of a either the beginning or end of a line.

- The construction of a frame.

- The construction of a surface.

- The punctuation of a point on a surface.

Given this limited set of design conditions, Sullivan employed three basic forms of ornament (Figure 1):

- The Medallion or geometrically (biaxiallysymmetric) structured type (Figure 1).

- The "Urpflanze" proto-plant or Root-Stem-Bloom, an axially structured type $^{7}$ (Figure 2).

- The Still-life type or "Arabesque" as Riegl calls it, a space-filling type (Figure 3).

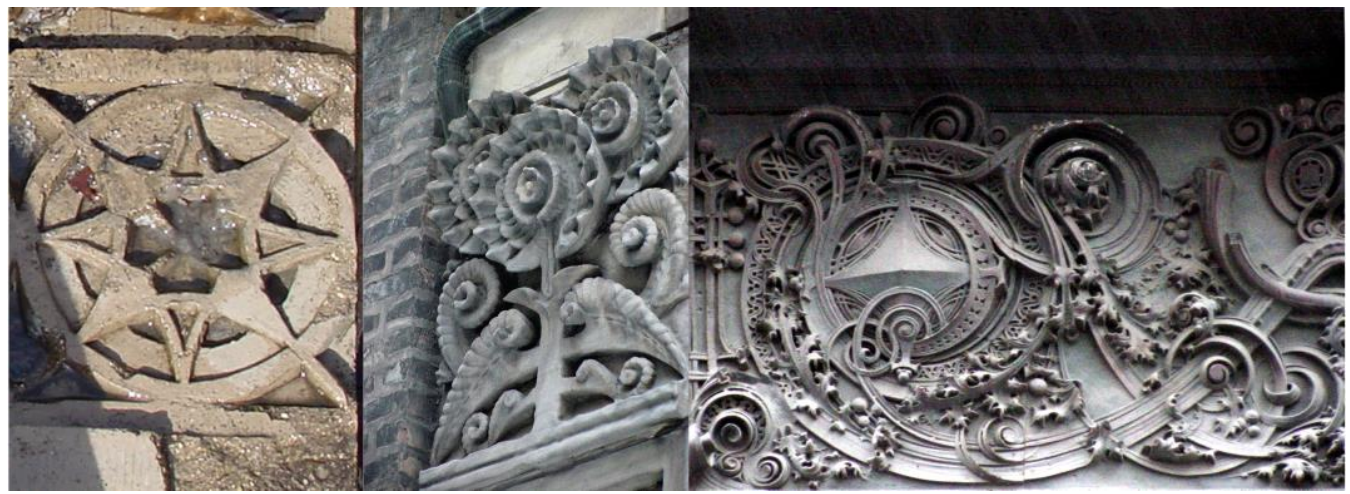

Figure 1. (Left to Right) Medallion Type, Urpflanze Type, and Arabesque Type Ornament

Source: Author.

The medallion type is characterized by its symmetrical rotation about a center. After 1888 this seems to be Sullivan's view of the plant in plan view, the same view Riegl refers to as frontal view. The medallion type seems to mature during the auditorium theatre, and is present as the spiraling leaf ceiling panel found in the main lobby, the panel also used by Frank Lloyd Wright as the in the corners of the living room ceiling at his Oak Park house in 1888.

7. Sullivan, The Autobiography of an Idea, 1956, 207. Sullivan himself describes this formtype as a building-as-ornament proposition in this passage from "The Tall Building Artistically Considered" addressing the tripartite composition of the tall building: "They quote the suitable flower with its bunch of leaves at the earth, its long graceful stem, carrying the gorgeous single flower. They point to the pine-tree, its massy roots, its lithe, uninterrupted trunk, its tuft of green high in the air. Thus, they say, should be the design of the tall office building: again in three parts vertically." 


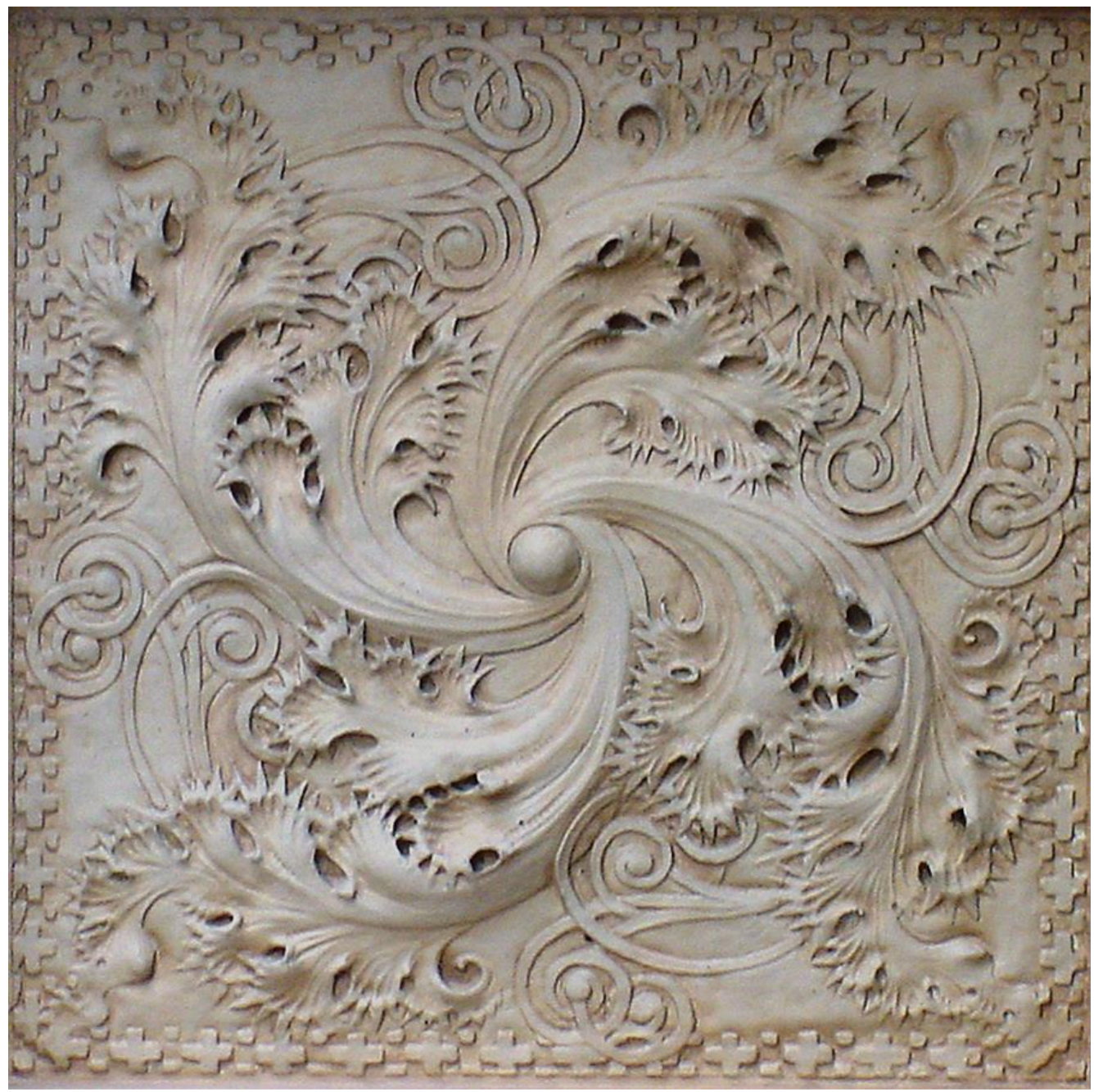

Figure 2. Auditorium Lobby Medallion Type

Source: Author.

The root-stem-bloom or axially organized type, is characterized by the relation of the ornament parts to a vertical axis and is often botanically accurate with root mass at the bottom, stem structure in the middle, and bloom structure(s) in the upper portion. This is similar to the "primal plant" or "Urpflanze" proposed by Goethe ${ }^{8}$ (Figure 3). These root-stem-bloom or axially organized ornaments often articulate anatomical components from botanical sources. The articulation of root, stem and bloom structures makes this ornament, Sullivan's view of the plant in elevation view, referred to by Riegl as the profile view. These ornaments originate with the root structures and the cotyledon or "seed germ" as Sullivan called it in "A System." Leaf, bud, and axillary bloom structures are arranged on either side of the stem/axis and a terminal bloom is frequently placed at the upper terminus of the axis. This ornament type does not appear to play a role in the conversion of ornamental structure to architectural works for Sullivan who's

8. J. W. von Goethe, Versuch die Metamorphose der Pflanzen zu Erklären (Gotha: Ettinger, 1790). 
works seem more focused on the medallion type later in his life, Frank Lloyd Wright however, seems to exploit this ornamental type as the basis for many of his "Prairie" houses from 1909 until his "Usonian" houses of the 1920's. ' (Figure 4).

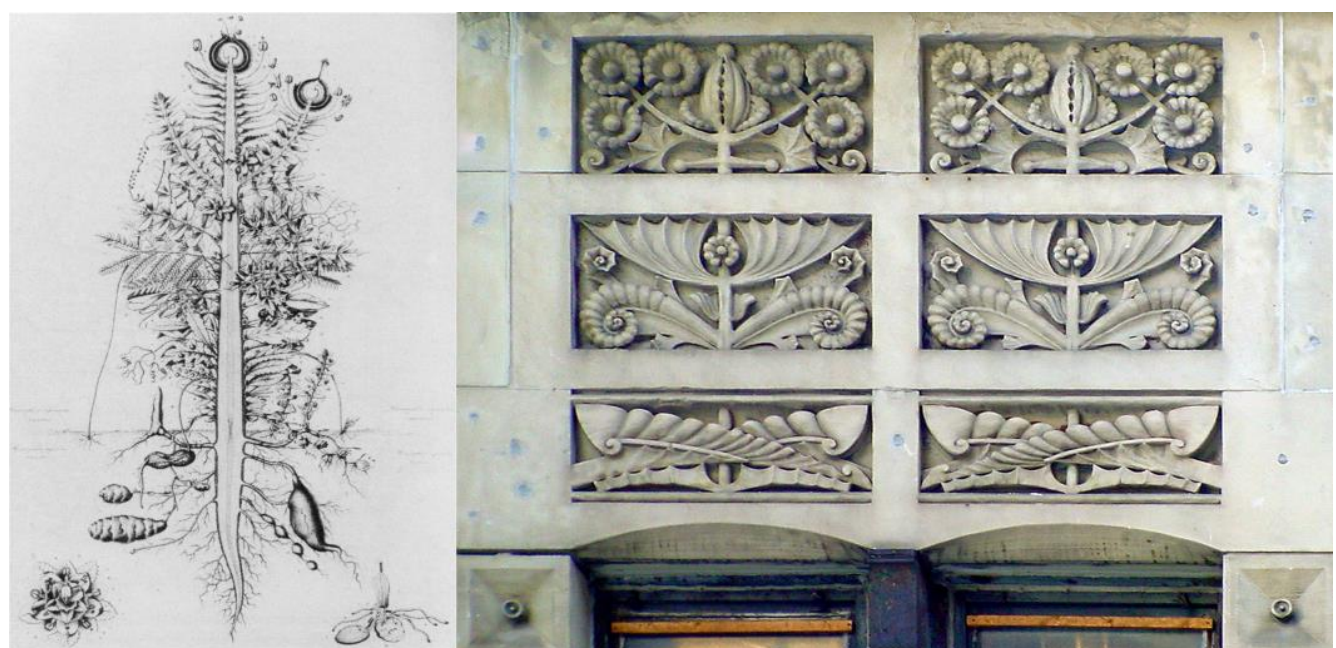

Figure 3. (Left) Goethe's “Urpflanze” Proto-Plant Sullivan, (Right) Jeweler's Root-Stem-Bloom

Source: (Left) Wikimedia Commons (Right) Author.
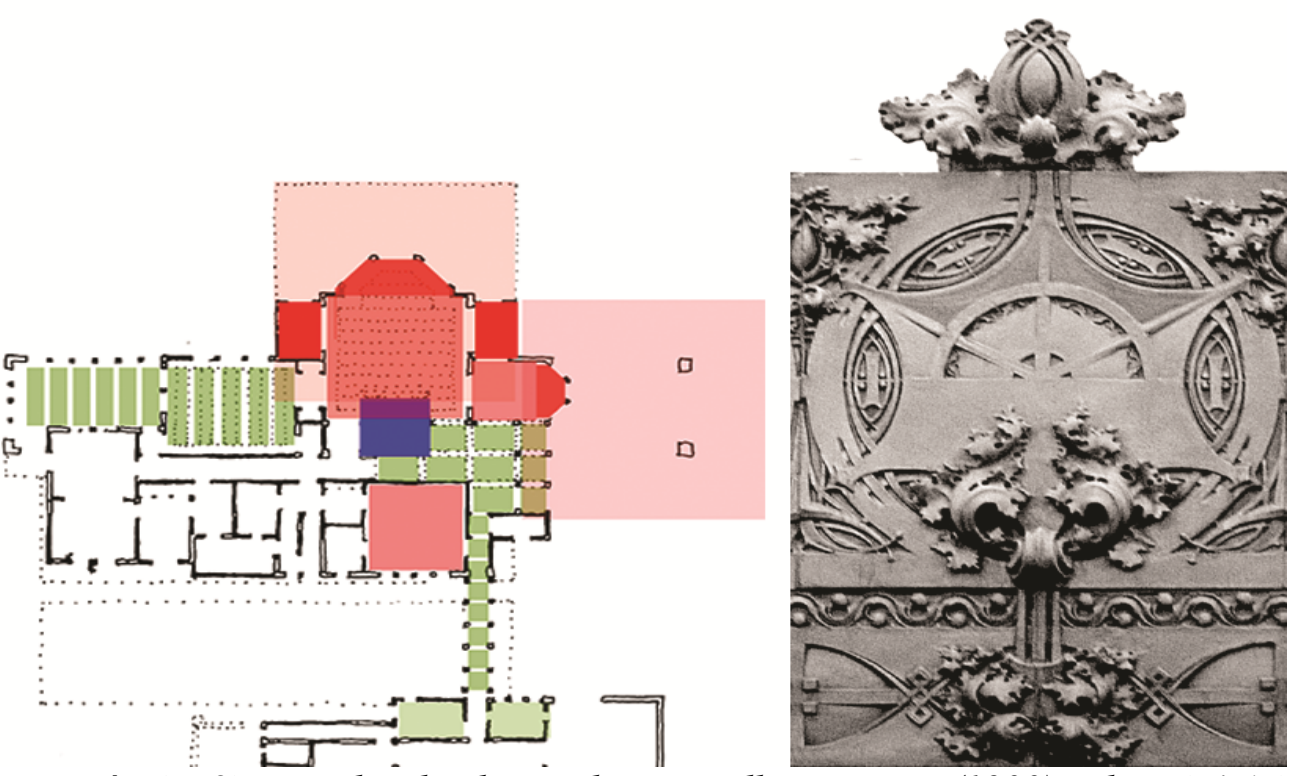

Figure 4. (Left) Frank Lloyd Wright's Bradley House (1900) Plan (Right) Sullivan, Sullivan's Merchants National Bank, Grinnell

Source: Author.

The still-life type is characterized by carefully composed writhing organic elements structured by their enclosing frame. The term "still life" has been used in painting to describe an arrangement of objects since the $15^{\text {th }}$ century BCE. Like the still life in painting, which emerged as a recognized genre in the $17^{\text {th }}$ century,

9. M. O’Brien, “After the Starchitect,” Athens Journal of Architecture 5, no. 3 (2019). 
Sullivan's still life is carefully composed arrangement of natural objects/motifs. ${ }^{10}$ Riegl's term for this is "The Arabesque" and explanation of the development of the vegetal tendril in early Islamic art offers important insight into this most complex of Sullivan's ornamental forms. Riegl proposes that the development from representational sculpture to artistic interpretation of nature occurs at the moment that the line is employed to describe the edges of the sculpture. ${ }^{11} \mathrm{He}$ proposes this is the moment of birth for the line, and from this point forward, the line becomes the primary problem-solving tool of the artist constructing ornament. The complex overlay of tendril, leaf, and bud forms in Sullivan's still-life ornament serves to carry the eye across the surface, rising, falling, pausing, moving counter to the primary direction often until our eyes return to the point of entry. Examples of these still-life floral arrangements can be seen throughout Sullivan's projects beginning as early as 1882 in the Hammond Library gable ornament. The still-life is frequently found in places where the irregular surface spaces required ornamental development. Some examples would be, in console shaped brackets (Figure 5) concealing asymmetrical gussets, lunettes, chimney panels and spandrels. The still-life may have been the ornament most frequently designed by Sullivan himself as the more-simple medallion and root-stem-bloom types can be substantially constructed with mechanical means and don't seem to require the consummate judgement of rhythm, line, balance and tension required by the stilllife.

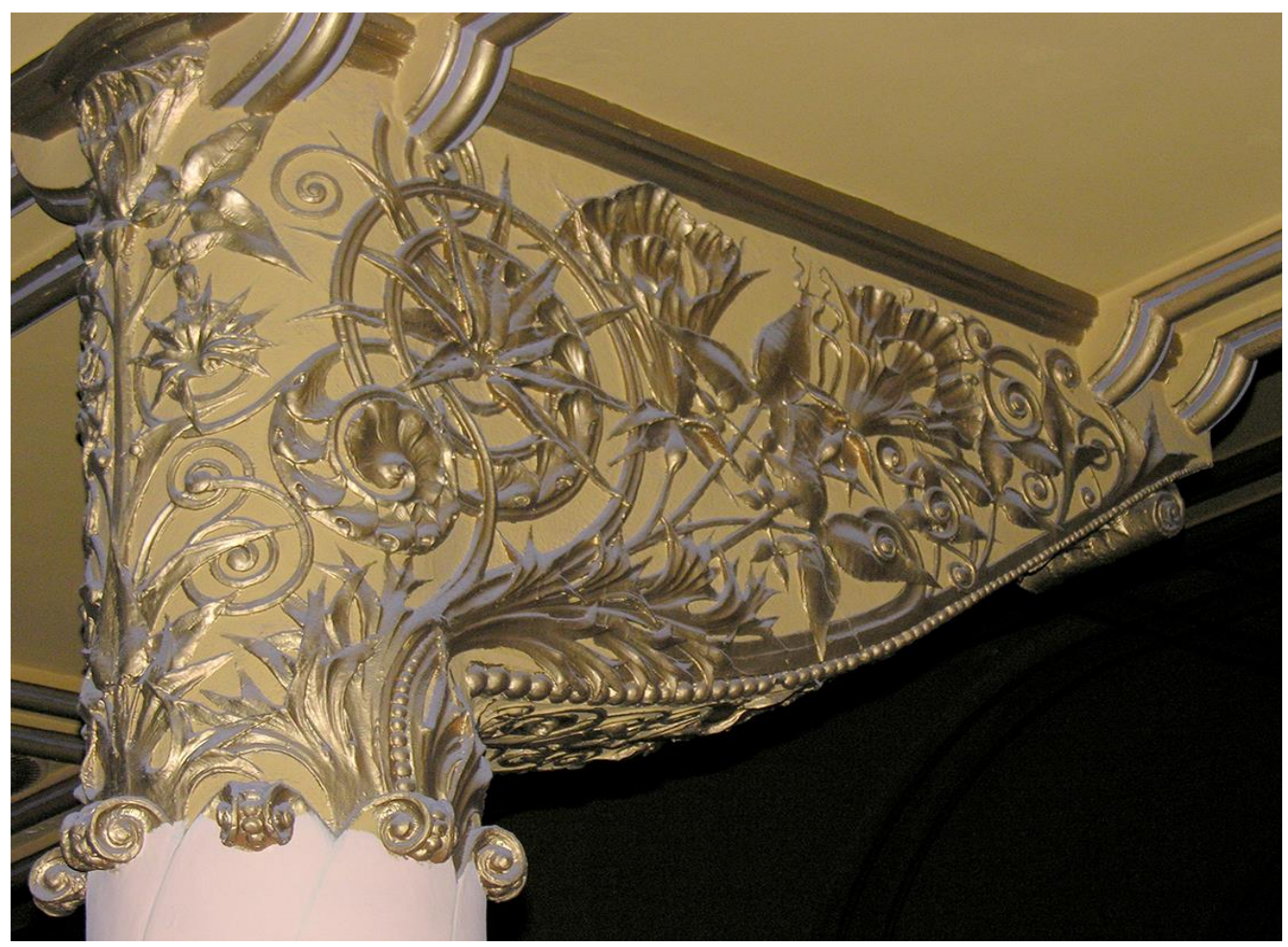

Figure 5. The Still-Life Type, the Arabesque

Source: Author.

10. J. Hawkins and S. Le Roux, The Oxford Reference Dictionary (Clarendon Press, 1986). 11. Riegl, The Problems of Style: Foundations for a History of Ornament, 1993, 29-30. 
The still-life is one ornamental form that Sullivan may not have entrusted even to the accomplished Frank Lloyd Wright in his role as Sullivan's apprentice. Perhaps the only apprentice to approach Sullivan's genius with the still-life is George Elmslie. Even with Elmslie's accomplished skills, the still-life ornament attributed to him by Paul Sprague often favor the powerful tendril, overcoming the other elements and not achieving the delicate movement, pause, counterpoint and balance present in the still-life ornament designed by Sullivan's own hand.

The medallion and root-stem-bloom ornament types were used as both isolated figural ornaments, and in parallel patterns articulating mass edges such as cornices, arch intrados, and stringcourses.

\section{A Closer Consideration of Sullivan's Medallion Ornament Type}

Because Sullivan's medallion-type ornament seems to play an essential role in the translation of scale from object to the building scale in Wright's and also in Sullivan's later works, this section will consider the type in greater detail. ${ }^{12}$

The medallion ornament type is distinguished from the root-stem-bloom and still-life types by a strong visual reinforcement of the center and elements rotated about that center in a radial arrangement resulting in biaxial symmetry.

The medallion form type of ornament is the example used by Sullivan uses to present the morphological development of ornament in "A System of Architectural Ornament." The circle, square, octagon, hexagon, pentagon and triangle are presented, as Sullivan has termed, the "containers of energy" which the seed germ (cotyledon) is placed at the very center. The seed develops according to its laws of plant morphology (as described by Asa Grey), but the seeds growth follows along the lines of the major and minor axis of the container's geometry, with the axis acting as a geometric trellis. As the organic energy grows along the axis, it breaches the container's perimeter at the point where the axis crosses the perimeter. At the site of this breach, the organic energy (implicitly contained in the geometric container) bursts outward, depositing itself on the surface of the geometric container as vegetal efflorescence (Figure 6).

In labeling this explosion of energy 'efflorescence' - that which is within, deposited on the surface, Sullivan proposes, without words, that the inert, or crystalline nature of geometric forms contain within them great quantities of a vital organic energy. Not a fractal similarity where a square contains the energy of more small squares, but contains the opposite. Geometry, rationality contains the organic, the emotional.

12. T. H. Beeby, "The Grammar of Ornament/Ornament as Grammar," in Ornament (ed) Stephen Kieran (Philadelphia: Graduate School of Fine Arts, University of Pennsylvania, 1977): 26.

13. Sullivan, "A System of Architectural Ornament according with a Philosophy of Man's Powers," 1924. 


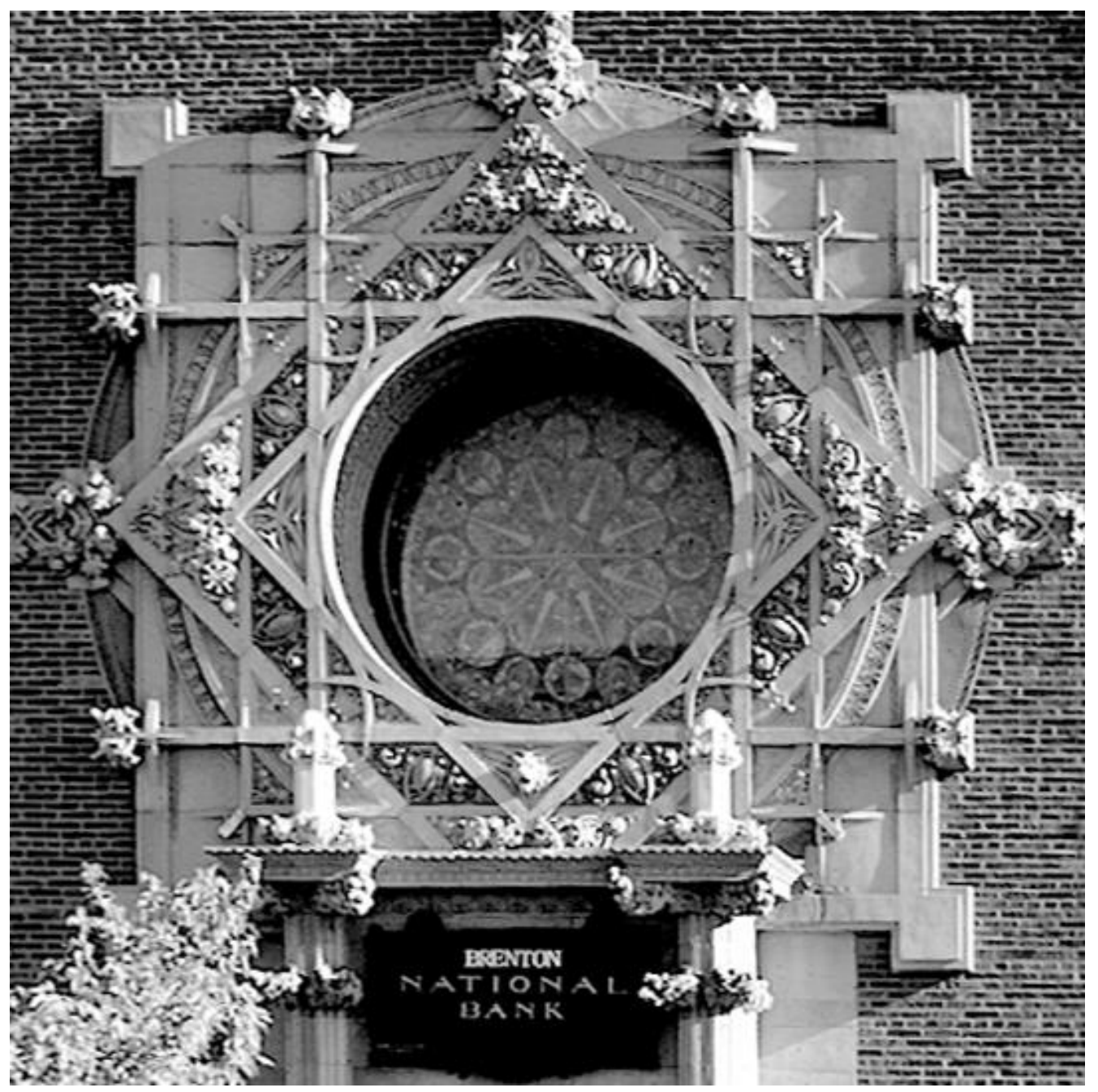

Figure 6. Efflorescent Bursts at Axial/Geometric Intersections. Powishiek County Bank

Source: Author.

These organic bursts of efflorescence are described by Sullivan as sub-centers of energy. These sub-centers effectively bind the concentric overlays of geometry together weaving over and under each geometric layer and ultimately reaching beyond the ornamental frame to bind the ornamental element to its background.

In "A System" Sullivan also refers the reader to "Grays School and Field book of Botany" " by Asa Gray, as his definitive source for scientific information on plant physiology and growth morphology. Gray provides a morphological explanation of the anatomy of various types of plants and flowers following the stages of growth. Sullivan's ornament seems to depend upon a few key anatomical parts, the seed germ with its nourishing cotyledon leaves, the stem, with its

14. A. Gray and A. Gray, Gray's School and Field Book of Botany: Consisting of "Lessons in Botany," and "Field, Forest and Garden Botany" (New York: Ivison, Blakeman, Taylor \& Co., 1874). 
terminal and axillary buds, and the calyx or flower cup below the bloom and the corolla, or the bloom itself.

Gray illustrates these anatomical parts in plan, section, and elevation views. Upon close review Sullivan's (1891) Schiller theatre proscenium medallion, the "Star Pod" reveals five to six concentric forms originating in the medallion center.

The first (1) is an undulating line of varying thickness that closely follows the radially arranged seed pods. This undulating line overlaps a hexagon (2) and is raised a very slight amount above it. The undulating line is unusual in that it is made up of broad areas of undeveloped surface similar to the next three concentric elements $(3,4,5)$. The lack of surface articulation, the close mapping of the undulations with the seed pods, and the additional concentric layers possess a striking similarity to Gray's illustration of a Linden calyx from figure 223 on page 109 the radial arrangement of the seed pods around the central axis (placenta) is also similar to the cutaway of a St. John's Wort calyx shown in figure 256 on page 118 of Gray's text. Grays figure 256 shows this radial arrangement in a partial cutaway that confirms this is a plan view cut through a calyx. The undulating lines are the enclosing tube of the calyx surrounding the seeds. A similar relation between undulating line and seeds arrayed around an axis can be observed by making a horizontal cut in a green or bell pepper (Figure 7).

Gray also presents the spiral as nature's way of packing leaves within buds, vernation. The paired and single spirals are presented using Carl Linneaus's original figures $153,154,155$ on page 76 . The spiral in the context of vernation within buds is a strong symbol of potential energy during the unfolding of the leaf upon the bud's opening and is often used by Sullivan in the early period to energize the ornament. In the second and third period medallion types, the spiral becomes a secondary and tertiary concern as the integration with geometry stabilizes many of the ornamental compositions. In what I am calling the "still life" and "root-stem-bloom" ornament types, the spiral is frequently used near the perimeter and ends of lines to continue the impression of energized growth.
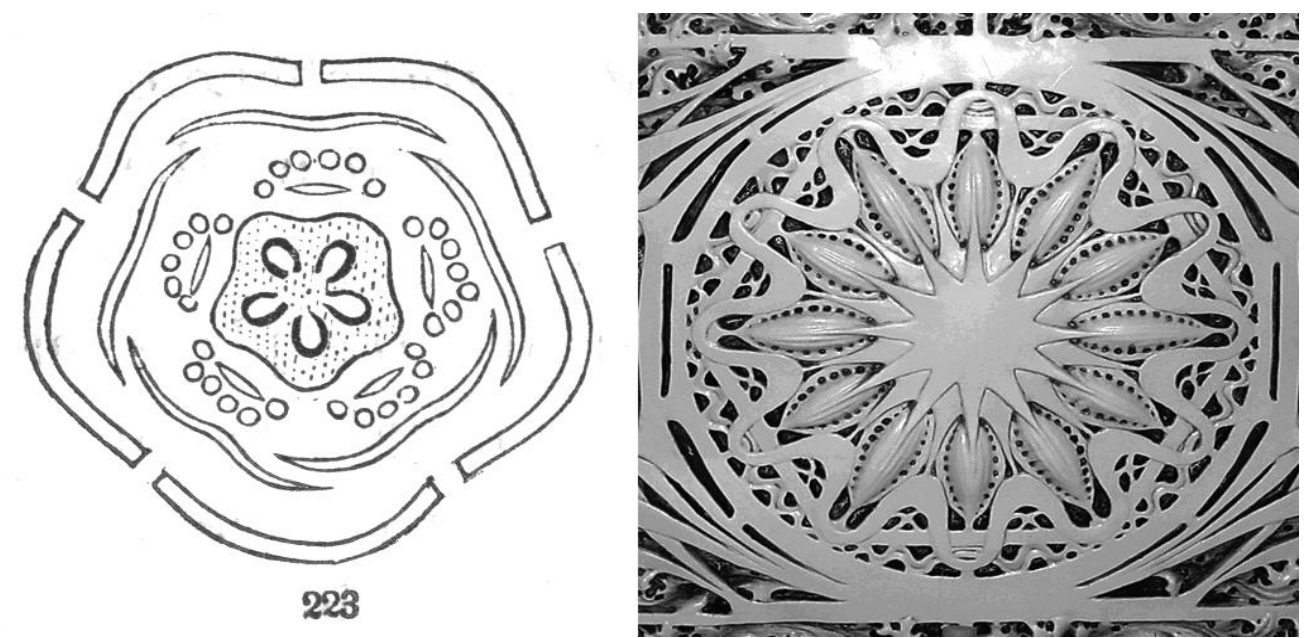

Figure 7. (Left) Asa Gray's Illustration of the Seed Pod Cut Horizontally, (Right) Sullivan's Schiller/Garrick Theater "Star Pod" Ornament

Source: (Left) Figure 223 from Asa Grays 1880 publication "Grays School and Field Book of Botany" (Right) Author. 
The close correspondence of ornamental parts with plant anatomy suggest that the increasing naturalism cited by Sprague was due in some part to Sullivan's close reading of Asa Gray's 1880 publication "Gray's School and Field Book of Botany." 15

\section{Energizing Strategies}

Conceptually, one might consider Sullivan's medallion-type to be very similar to the classical rosette as an ornamental form. In Early works, such as the Halstad Flats, (1884) Sullivan employs the lotus flower as a singular element and as a definition of the geometric center of a larger ornamental field. This more visually "static" medallion falls out of use in Sullivan's medallions by the mid-1880's. From the mid-1880's on, Sullivan seems to be exploring various approaches to increase the visual energy of the medallion. I categorize these approaches as follows:

- Energized emanations

- Spiral rotation

- Wind Swept

- The Pulsar

- Ready-to-burst

Each approach seems to have been favored by Sullivan for various lengths of time. Perhaps this is an indication of his satisfaction with the success of the energizing strategy, or of its potential for development. The number of medalliontype artifacts available for study in either as physical or photographic form is small enough that these categories cannot be considered the full extent of Sullivan's approaches.

\section{Energized Emanations}

The chimney panel from the 1884 Reuben Rubel residence (Figure 8) combines two forms of tendrils to enforce the energized center of the panel. The uppermost layer of tendrils emanate in sinuous curves across the major spiral below. This is one of the only examples of an energized tendril emanating from the center used by Sullivan. The tendril itself is un-natural in appearance, originating from an impossibly narrow taper on the surface of the low-domical form at panel center, then contorting through seven undulations and terminating with a narrow taper very similar to the tendril's origin. This "narrow origin to narrow terminus" may have been seen by Sullivan as an unsatisfactory signifier of the reservoir of energy at the panel's center.

15. P. E. Sprague, The Architectural Ornament of Louis Sullivan and his Chief Draftsmen. Doctoral Dissertation (Princeton, NJ: Princeton University, 1969). 


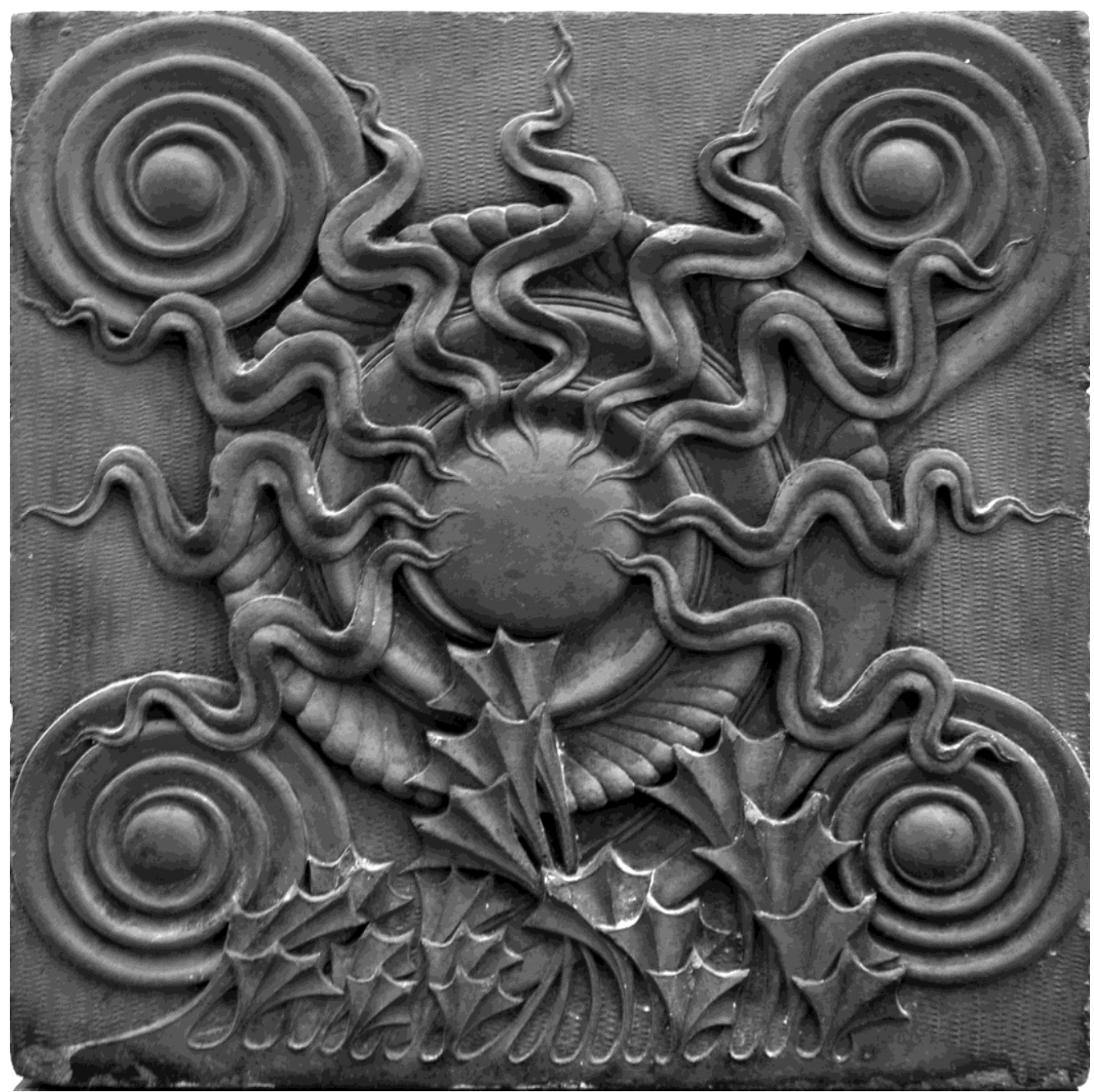

Figure 8. Rubel House Panel

Source: Author, by permission of the Louis Sullivan Collection at Southern Illinois University.

\section{Wind Swept}

As if the base spiral, corner spirals and emanating tendrils in the Rueben panel were not enough, Sullivan adds a field of wind-swept palmette-leaves at the bottom of the panel that confirm this is an elevation-view of the energy-center. These leaves sweep up and towards the center of the major spiral but originate at the bottom of the panel, competing with the center itself as the source of energy. Like the previously discussed approach, the wind-swept energizing approach appears to have been short-lived in Sullivan's work.

\section{Spiral Rotation}

In this early period, 1873 - 1890 Sullivan employs the spiral as a form of vernation in an effort to infuse life into the ornament by suggesting the spiral's uncoiling. From 1890 through 1905 the spiral becomes a minor structure, used to fill small areas. Geometric elements dominate the medallion structure during this 
period. This is interesting as the circle, square, octagon and hexagon are forms that have a strong sense of visual stability, inherently lacking the dynamism of the spiral.

The Rubel house is characteristic of the early period of Sullivan's ornament in that the spiral is a frequent subject of the ornament. Beneath the emanating tendrils discussed above lies a large spiral, articulated with a series of spirally concentric segments. In nature, one might find this form common to the fiddleneck fern, so named for its similarity of appearance when emerging from the ground to the neck of a violin. The spiral presents the appearance of potential energy, just as a coiled spring does. The Rubel panel has four symmetrically arranged spirals spinning out from beneath the center spiral bringing energy to the corners of the panel, and a tension to the static masonry elements framing the panel edges.The spiral structures in the 1886 Eda Holzheimer ceiling escutcheon (Figure 9) are more deeply integrated into the structure of the whole than the Rubel panel. This may be related to this escutcheon having been designed to be viewed from below, rather than from the side. The fixture held the escutcheon center, and the four corner spirals spin off from a tendril that attaches itself, not quite tangent to the center. Each corner spiral has a pair of smaller serpent-like tendrils on its surface, emanating from the corner spiral's center itself. Filling between the corner spirals on the orthogonal axis of the escutcheon are spiral palmettes whose origins are unclear. They seem to emerge from the plaster ceiling itself, between a tangle of minor tendrils filling the field between corner spiral and center; whatever their origin is, three segments of these spiral palmettes terminate emphatically in spherical objects. Overall, the similarity in size between the center, the spirals falling at the corners and those falling on the orthogonal centerlines of the escutcheon eliminate the chance for a simple hierarchical reading of the escutcheon. The overall impression is a dense mass of energy generally originating at the point (the leak) where the light fixture pierces the plaster ceiling, an approach to efflorescence not seen again until the design of the Farmers and Merchants Bank at Owatonna twenty-one years later.

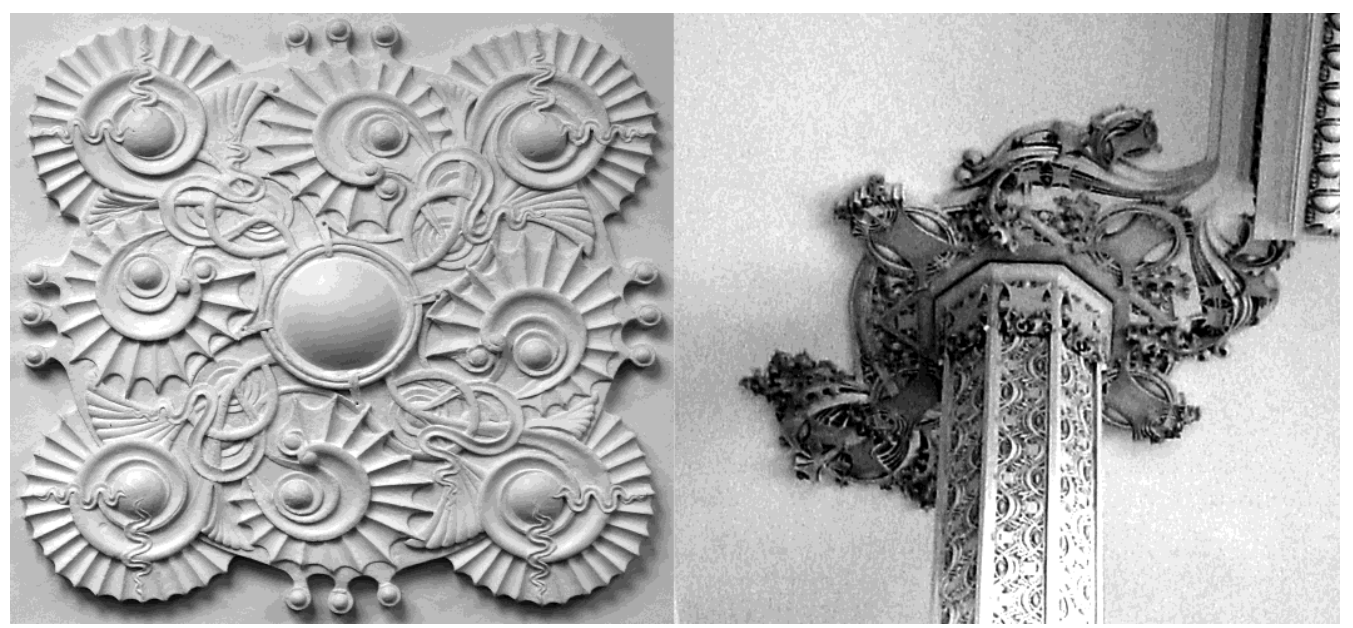

Figure 9. (Left) Edith Holzheimer Ceiling Escutcheon (Right) Farmers and Merchants Lightolier Escutcheon

Source: Author. 
The spiral structure appears again in the door panel for the 1885 Samuel Stern Residence. Like the panel at the Rubel Residence, this is intended to be seen in elevation. In this door panel, the spiral is not apparent as a form, rather it appears as a structure in the left-hand bud overlap on the leaves. Were it not for these volute-shaped bud structures, the leaves located on and favoring the diagonal axis would propose a static composition. Below the leaves and emanating directly from the lotus flower in the center are frond structures that meet the flower off-axis to suggest another spiral direction. The significance of this door panel lies in its being the earliest example of Sullivan employing a spiral structure without making the spiral fiddleneck fern.

The surviving physical and photographic record of Sullivan's ornament suggests that Sullivan seldom used the spiral as a major ornamental subject following their role Auditorium Theatre as ceiling panels. These panels were intended to be viewed from below and like the Holzheimer ceiling escutcheon are likely to have been escutcheons for light fixtures meant to be viewed from below. The spiral is clearly presented by sweeping tendrils and leaf-structures from the tangent of the center out away from the center to unfurl at the corners of the panel.

This approach to bringing the energy from the center to the corner, then ending it with unfurled leaves is the most successful of the spiral medallion series as it presents energy and reinforces the center with a single tendril developed in high relief, and with great detail that assists one's eye in travel from the corner edges around the spiral to the center. The orthogonal centerline/edge intersections are present, but with low relief, thin tendrils, clearly conceding the stability of the panel to the center to corner spiral. The panel is bordered with stable orthogonal cruciform shapes visual stabilizers of the edge which are frequently overlaid by both the low-relief spirals and leaf elements from the high-relief tendrils. Thus, the resolution of the tension between the stability of the square panel, and the dynamism of the spiral is further decided in favor of the spiral.

It is interesting to note the context of the disappearance of the spiral as a primary figure in Sullivan's approach to energizing the appearance of the medallion-type ornament. The completion of the Auditorium building in 1889 seems to mark a significant decline, virtual disappearance, of the primary spiral in Sullivan's ornament. The spiral did not re-emerge again until 1907 in the office annex for the Farmers and Merchants Bank in Owatonna Minnesota. This was George Elmislie's last project with Sullivan, and in letters to the Bank's owner, Carl Bennett, Elmslie clearly stated his primary role in the design of the bank and its details. ${ }^{16}$ If this late re-appearance of the spiral is credited to Elmslie one could conclude that the disappearance of the spiral from the "ornament record" after the Auditorium reflects some disappointment or some perceived shortcoming of the spiral by Sullivan to adequately reflect the energy within a building.

16. L. Millett, Curve of the Arch: The Story of Louis Sullivan's Owatonna Bank (St. Paul, MN: Minnesota Historical Society Press, 1985), 56. 


\section{The Pulsar}

In the 1890 Getty Tomb (Figure 10), Sullivan stretches a fabric of octagons across the face of the tomb, providing a scalar measuring unit to preserve the whole. The octagon is present as a geometric container. Within its perimeter, lines of spheres extend along the orthogonal and diagonal axis from the center to the octagons eight flat sides. The spheres diminish in dimension from center to edge, reinforced at the center with a solid mass and increased depth of the relief. The scale change in the diameter of the spheres provides a diminishing incremental scale for our eyes reading of the distance between center and perimeter. The scale increment makes the overall perception a series of concentric pulses emanating from the center. These pulses end at a low-relief inner bordering octagon inscribed within the high relief perimeter of the octagon. The only dynamism in this ornament is found in this concentric pulsing from center to edge.

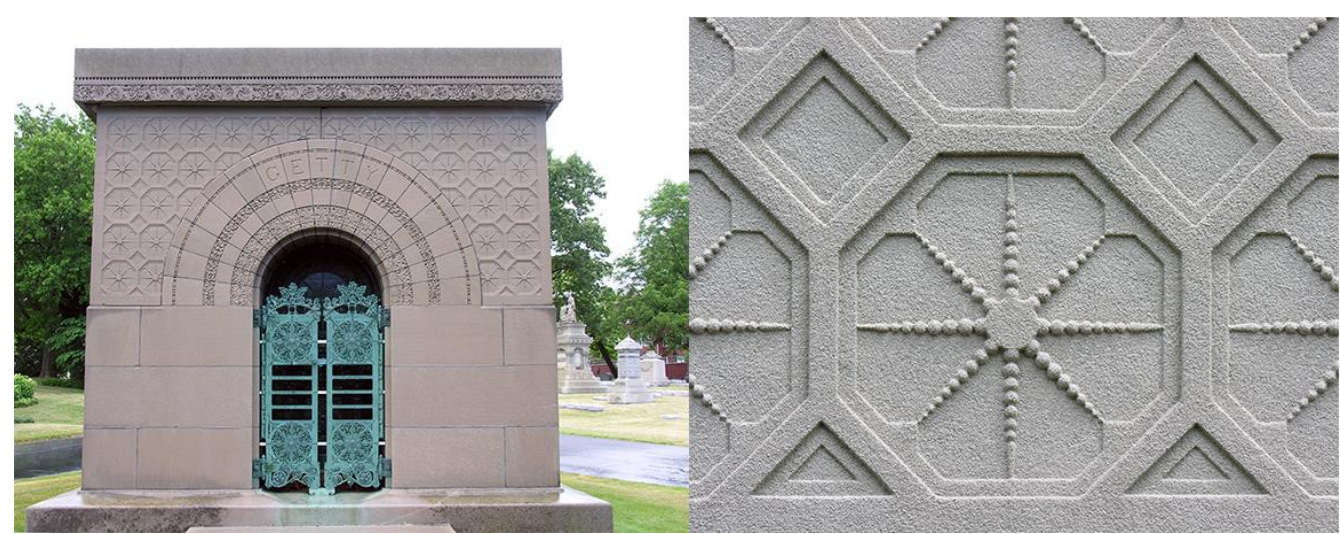

Figure 10. (Left) Getty Tomb 1890 (Right) Pulsar Ornament from the Getty Tomb Source: Author.

The Pulsar and the Analytical Plan

During this same time period (1892-1895) anatomical elements and structures themselves appear as the symbol of nature's dynamism in medallion-form ornament from the St. Nicholas Hotel, Schiller Theatre, and Guaranty Building. Asa Gray's text ${ }^{17}$ seems to be an important source during this period, as neither Ruprich-Robert, Owen Jones, or Christopher Dresser penetrates the surface appearance of their plant subjects to reveal the anatomical structure of the plant.

Gray's text goes so far as to title lesson 13 as "The plan of the flower" and proceeds to illustrate the seed pod much as an architect might, cutting planshorizontal sections through the seed pod to present the relationship of the seed clusters to the central axis and to the surrounding enclosure of the pod (calyx) itself.

The previously discussed Schiller Theatre Proscenium ornament, (Figure 7) referred to as the "Star Pod" is a prime example and is perhaps the most literal

17. Gray and Gray, Gray's School and Field Book of Botany: Consisting of "Lessons in Botany", and "Field, Forest and Garden Botany" 1874. 
reference to the plant cut in an architects plan view. If Gray's Botany is discounted, this clinical dissection of a seed pod seems to be an unprecedented ornamental subject. More importantly, is this act of presenting what was within the plant, not its outward appearance an affirmation of a principle that values what is within, equally with the outward appearance of things? Critics of Jordy's stature ${ }^{18}$ approached this question, but made their critique expecting the substance "within" to be the constructive means of the building. Their critique adequately identifies the shortcomings of such an approach based on false pilasters, exterior columns disappearing as they approached the earth, etc. But if the "within" was the collected energy of the spirit of the building filled with people then the outward appearance would be more focused on presenting this energy rather than the constructive means of the building. The analytical plan of the plant, as ornament seems to be completely unique to Sullivan, and may be the key to the parallel between his ornament and buildings.

"The Cell in Development and Heredity" by Edmund Wilson, 1896 was the only other book recommended by Sullivan in "A System of Architectural Ornament." Wilson's book was considered the standard text for its time in the rapidly emerging field of cellular biology. But beyond the facts and principles related to cell development and genetics, what was Sullivan's interest here? Certainly, this microscopic scale of nature was not easily observed by Sullivan, though the confirmation of an internal intelligence held at the cellular level in chromosomes must have been interesting to Sullivan. ${ }^{19}$ But what does Wilson contribute to form, structure, and order, Sullivan's core questions?

I propose that the geometric clarity that emerges during cellular division as illustrated by Wilson is one such contribution. The fusion of the geometric and the organic is only possible at that moment when the organic submits to a geometric order, during cellular mitosis. ${ }^{20}$ Conceptually, this may have been equal to the "rule having no exception" stated by Sullivan's mathematics tutor in Paris, Monsieur Clopet dramatically recalled by Sullivan in "An Autobiography of an Idea."21

Wilson's diagram of the protoplasmic cell-connections, circular nuclei embedded in the center of hexagons in a matrix held together by "fine bridges" that connect the nuclei to nuclei is a compelling prospect as a source for Sullivan's ornament (Figure 11).

Had Wilson's book been published prior to 1896, one would be tempted to propose that Sullivan had been inspired by this diagram in making the hexagonal pulsar-network across the surfaces of the Getty Tomb. It would even be tempting to consider that somehow Sullivan had heard Wilson's lectures in 1892 perhaps accompanied by sketches or diagrams and been inspired to the Getty ornament.

18. W. Jordy, American Buildings and their Architects: Progressive and Academic Ideals at the Turn of the Twentieth Century (New York: Anchor Books, 1972), 83-179. 1896).

19. E. Wilson, The Cell in Development and Heredity (New York: MacMillen Company,

20. Ibid, 249.

21. Sullivan, The Autobiography of an Idea, 1956, 165, 220-221. 
The facts do not allow for such speculation however, as the Getty tomb predates even Wilson's lectures by two years.

Wilson's book and illustrations must have been a strong affirmation in Sullivan's rule-having-no-exception, the inter-relationship between the organic and inorganic (being the symmetries that occur during cellular division) for him to have cited it in "A System" but there is no evidence in his ornament to support its role as precedent.

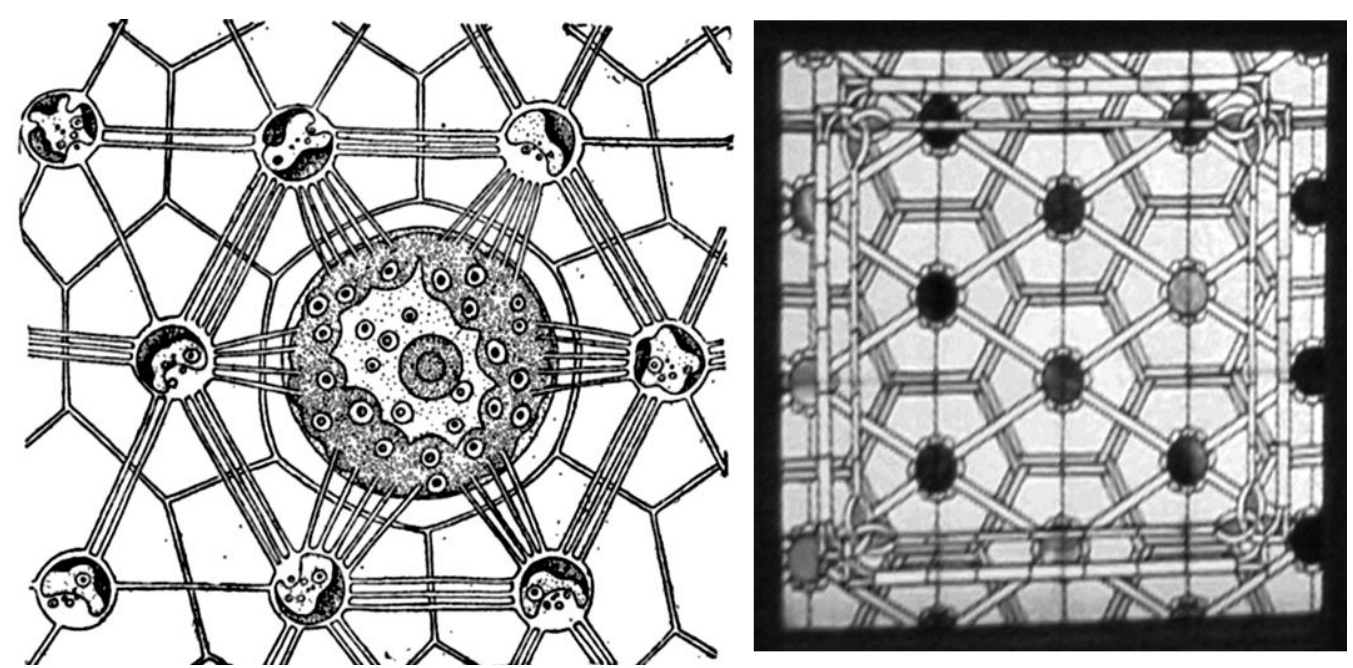

Figure 11. (Left) Edmund Wilson, Cell Development and Heredity (Right) Stained Glass Soffit Pattern, Stock Exchange Trading Room by Sullivan

Source: (Left) Edmund Wilson's 1896 Cell Development and Heredity (Right) Author.

Ready-to-Burst

Discovery of the correspondence between biaxial symmetry during cellular division and his own observations of nature's process for ripening and releasing seeds from spent flowers seems to merge in the next set of Sullivan's medalliontype ornament dating between 1890 and 1893.

In the "Curve of the Arch: The Story of Louis Sullivan's Owatonna Bank" Author Larry Millett noted "His best buildings seem almost to pulsate as the ornament dances along the surface, bringing the block to life. And yet the ornament is always contained within the larger framework of his buildings. This quality of barely contained energy, which Sullivan described as "mobile serenity," is the hallmark of his ornamental style." 22 In this passage, Millett describes the purpose of the ready-to-burst approach to energizing medallion type ornament, to barely contain energy as though it would burst out of its terra-cotta and iron container into a burst of efflorescent growth at any moment.

Beginning with the medallion from the elevator enclosure at the Chicago Stock Exchange (1890) (Figure 12), one can observe that the vegetal elements of the ornament project from its surface in a roughly circular field. These projecting elements fill arc sections between the perimeter circle and the inner square

22. Millett, Curve of the Arch: The Story of Louis Sullivan's Owatonna Bank, 1985, 78. 
providing the impression that the circle is actually spherical and is pushing through and around the square. To emphasize the immanence of the sphere's bursting, Sullivan restates the square, this time rotating it within the inner square. Within the rotated square is an element defining a circular field. Arcs tracing oval shapes fill the circular field are oriented along the primary (orthogonal) axis of the circle. The effect is suggestive of a sphere, emerging from the inner square, a sphere, ripe with seeds that is beginning to crack (oval shapes) to release its seeds. In this process of being deformed, the square is transformed from the inorganic form of the crystal to an organic membrane on the verge of rupture by an irrepressible life force behind it. This form, (the square, deformed to the brink of rupture by the life-force) found as both a square-origin and a rectangular-origin is, as Millett suggests, a representation of the linking of the organic and inorganic. ${ }^{23}$

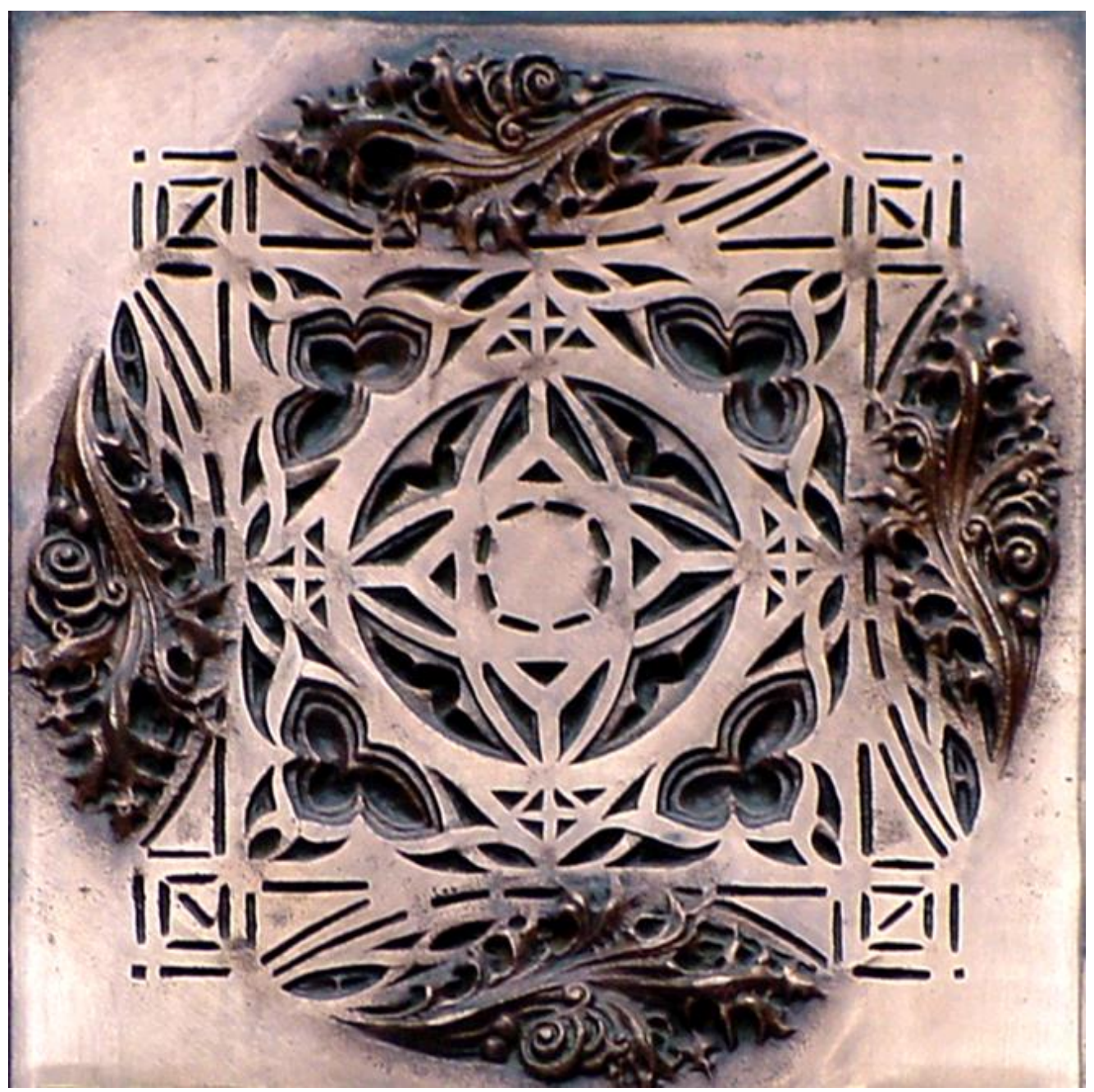

Figure 12. Portion of the Elevator Surround, Stock Exchange Source: Author. 
The ornament from the corner columns of the Meyer Building (1893) similar deformed square element in the major ornament. This ornament is actually a partial sphere projecting from the surface of the square vegetal field. The sphere is cracked open like a ripe seed pod along the lines of arcs forming overlapping squares with corners extended into spurs (or Wilsons "fine-bridges") making what Sprague has called these deformed squares, "shield-like" forms. The spurs can be seen two ways, one, as strong points of attachment for the square that is being distorted by a force behind it, trying to push through the center of the square, so the spurs are merely corners distorted by the strong force behind the square. Another possible reading is that the square is growing on the center axis, and is itself reaching with its corners to ultimately cover the organic elements of the ornament. The arcs made between a fibroblast cell's anchor points are very similar to the curved lines used to suggest spherical shapes in drawings. ${ }^{24}$

The idea that the building was alive, producing buds, seeds in pods ready to burst required Sullivan to "enter into communion with living and lifeless things.",25 This belief, stated by Sullivan in "A System" is the next step forward from the anthropometric treatment of the facade at the Auditorium.

\section{Methodology: Comparative and Figural Analysis}

After drawing the plans and sections of the following case study projects, chosen for their identical banking typology these Sullivan designed commissions, dating from 1907 to 1914 Sullivan's last set of commissions, a geometric and axial analysis was conducted to find correspondences with the generative principles of ornamental design articulated by Louis Sullivan in his 1924 publication "A System of Architectural Ornament According with a Philosophy of Man's Powers.

Mapping those correspondences with color upon plans and sections revealed both a relationship to the "Plate 1 Development of the Blank Block" from "A System" and to the primal plant in frontal view, the Urpflanze or Root-StemBloom structure employed by Sullivan from his earliest to his latest works.

Numerous publications authored by Sullivan himself, architectural critics and architectural historians informed the likelihood of correspondences which have been heretofore undocumented in the Sullivan literature.

\section{Rules for the Medallion-Type, Plate 1, A System of Architectural Ornament according with a Philosophy of Man's Powers}

It is the thesis of this paper that Plate 1 of "A System" is the closest exemplar of Sullivan's process for the conversion of ornament into building. Plate 1 graphically describes eleven steps to transform a square "blank block" into a fully 182.

24. Sprague, The Architectural Ornament of Louis Sullivan and his Chief Draftsmen, 1969,

25. Sullivan, A System of Architectural Ornament According with a Philosophy of Man's Powers, 1967, 2. 
developed ornament. These steps are not described by Sullivan in the text or captions, but will be generalized here to aid in the analysis of the building plans. Sullivan's steps proceed to develop both the organism and the supporting axial trellis's guiding its growth. The trellis development proceeds from the perimeter toward the center, while the organism develops from the center toward the perimeter. Sullivan shows eleven steps towards the completion of the medallion. Completion appears to be a state of balance between articulation of the supporting geometric trellis, and the organisms' full utilization of the same.

The development of the square to a fully effloresced ornament is generalized as follows (Figure 13):

Step 1: The blank square block.

Step 2: A concentric square is developed at the perimeter.

Step 3: The primary (orthogonal) and secondary (diagonal) axis appear and distort a second concentric square with an inflection at the primary axis intersection, tapering toward the center.

Step 4: A third concentric square, very close to the second is developed, the space between the second and third concentric square is depressed slightly as to "float" this third square.

Step 5: This third concentric square is anchored to the corners of the second by lines extending from the corners (forming squares themselves) to the inside perimeter of the second square.

Step 6: A rotated square is developed, with sufficient dimension as to have the four corners extend slightly under the axial distortions developed in Step 3.

Step 7: The perimeter of the third concentric square is raised so that the corner lines developed in Step 5 extend fully around this third concentric square. Another rotated square appears, slightly smaller and on the surface of the rotated square developed in Step 6.

Step 8: Diagonal axis are developed by a "bow-tie" element which is effectively a rectangular membrane, pinned at the corners, and pushed with a spherical object from behind, a variant on the "stressed" square membrane in the "ready-to-burst" medallion type. The "bow-tie" is positioned between the raised perimeter of the third concentric square and the lower rotated square developed in Step 6. The "bow-tie" is connected back towards the center with a line.

Step 9: A fourth concentric square is developed. It is positioned between the first and second concentric squares developed in Step 1 and 2. This square is effectively a pair of thin lines, anchored at the corners with square holes. The border around the third concentric square developed in step 7 is raised, and the inside edge of the second concentric square are stepped deeper into the base block.

Step 10: A circle is developed, subtracting mass from the second rotated square. The axial distortions developed in Step 3 are raised above the surface of the raised perimeter of the third concentric square and above the surface of both rotated squares. The effect is to make these axial distortions the "clasps" that hold the third concentric and both rotated squares to the surface while the 
tapering-toward-center form of these distortions focuses one's eye on the center circle. A border of square holes is developed in the width of the fourth concentric square developed in Step 9.

Step 11: This step is captioned by Sullivan "No. 11 represents No. 10 developed with increasing freedom, but still largely in the mechanical mode. Beginning Appearance of the imaginative Element." (punctuation added).

Step 11 can be generally described as infilling and elaborating the void spaces between the concentric and rotated squares. The border of square holes in the fourth concentric square described in Step 10 disappears, and is replaced by the fourth concentric square developing as a frame profile, raised above the surface of all the elements, including the blank block from Step 1. The corner developments are a miniature whole ornament with two concentric squares, a central circle subtraction, diagonal "bow-tie" elements oriented with their long axis parallel to the diagonal and acting as the clasps holding all the geometries together. The center is developed as four oval shapes arranged in a cruciform with their long axis parallel to the primary (orthogonal) axis of the larger whole.

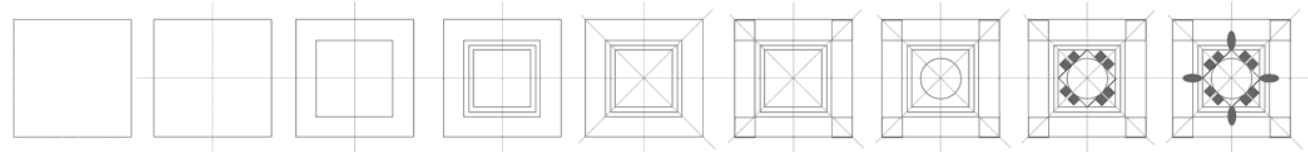

Figure 13. Illustration of Steps 1 through 11, Plate 1 of "A System" Source: Author.

To study the building as ornament speculation, Sullivan's eleven-step process has been simplified to the following:

Step 1: Establish the base block, the primary geometric container as the exterior perimeter of the dominant building mass. Draw the primary (orthogonal) and secondary (diagonal) axis.

Step 2: Overlay the secondary and tertiary concentric geometric containers. As defined by the building mass, teller wickets, light fixtures, skylights or other architectural elements.

Step 3: Where the primary (orthogonal) axis intersects the geometric containers (primary, secondary, or tertiary) identify the architectural elements holding the place of efflorescent bursts. These may be ornamental wickets, vaults, entry portals, murals, art glass windows or skylights.

Step 4: Where the secondary (diagonal) axis intersects the geometric containers (primary, secondary, or tertiary) identify the programmatic elements holding the place of efflorescent bursts. These may be the president's office, the men's exchange office, the women's exchange office, the book vault, safe deposit booths, secure stairs to lower levels. 


\section{Building as Ornament: Three Case Studies}

Considering the methods and morphological stages described in Plate 1 of " $\mathrm{A}$ System" one can propose a rational/mechanical development of Sullivan's ornament, and thus a foothold for developing a building plan and section according to similar morphology. Consider, for purposes of this proposition, the development of the plans and sections for three commissions from Sullivan's late period: The National Farmers Bank at Owatonna Minnesota, completed in 1907, The Merchants National Bank in Grinnell, Iowa, completed in 1914, and the Farmers and Merchants Union Bank in Columbus, Wisconsin completed in 1919.

While these case studies are all of the same typology, the rural bank, and are all rectangular or square in planform, the plan form is not given by the site in the case of the National Farmers bank, as a small office space was also constructed on the site, but site geometry was a primary factor in the plan form of The Merchants National Bank, and the Farmers and Merchants Union Bank, where lot size and geometry constrained Sullivan's choice of footprint.

Similarly, the rural bank as a typology did not impose a plan form per se upon Sullivan. The functional needs for the rural bank, teller line, vault, lobby and officers' spaces were the same as in most small town banks, but Sullivan's deployment and treatment of these functions was not limited by established typological norms.

The plan geometries themselves, while being reducible to similar subdivisions and unitized proportions as those seen in J.N.L. Durand's "Précis of the lectures on architecture" ${ }^{26}$ have been developed by Sullivan with his unique attention to both the geometry of the primary enclosure and the development of subgeometrical elements within, in both plan and section. An approach to geometries uniquely applied by Sullivan and his assistants.

A more exhaustive analysis could include all of Sullivan's commissions. Indeed, Jordy's diagrams of the primary facades of the high rises and banks tempt a speculation that at some point in time, Sullivan perceived the two scenarios for the building as an organism. ${ }^{27}$ In one scenario, the base of the building is considered to be a planter, the seed-germ is planted at the center of the planter, just below the surface, and the building above is considered the stem and blossom growing through a trellis-framework of steel columns and beams. In this scenario the first two floors, as the planter are filled with fine roots, delicate ornament, while the upper stories are made up of more coarse stems, shoots, leaves, buds and seeds (columns, spandrels and cornice).

In scenario two, Sullivan proposes that the basement is the planter and the seed germ is planted below grade. The stems emerge, climb to their maximum height and have a more uniform scale of surface refinement. The buildings constructed by Sullivan in scenario two are more fully integrated, have less contrast in scale, form, material, and color between the bottom and the top. Jordy

26. J.-N.-L. Durand and J.-N.-L. Durand, Précis of the Lectures on Architecture, with, Graphic Portion of the Lectures on Architecture (trans.) David Britt (Getty Research Institute, 2000).

27. Jordy, American Buildings and their Architects: Progressive and Academic Ideals at the Turn of the Twentieth Century, 1972, 152. 
comes close to making similar speculation, but stops short, perhaps a victim of his own expectations for Sullivan's work.

A preliminary grouping of buildings in each scenario may be:

Scenario One buildings:

Scenario Two buildings:

Schlesinger-Mayer

Wainwright

Guaranty

HomeBuilding Association

Van Allen Store

Merchants National Bank

Peoples Savings \& Loan

National Farmers Bank

Peoples Savings Bank

Farmers and Merchants Union Bank

Gage Group

Bayard

Union Trust

Meyer Building

Getty Tomb

In each scenario, the upper portion of the building represents a life-force emerging from the seed-germ planted somewhere below as explained by Sullivan in "The Tall Building Artistically Considered."

\section{Case \#1: Farmers and Merchants National Bank, Owatonna, Minnesota 1907}

The sixty-eight-foot square footprint of the outside dimension of the primary banking mass of the bank provides a "blank block" point of beginning for the plan (Figure 14). It is important to note that the actual site dimension is greater along Broadway, almost one hundred and thirty feet, so the sixty-eight-foot square dimension can be understood as an intentional act on the part of Sullivan and conceivably, his longtime associate, George Elmslie. Variations in wall thickness between the exterior walls facing the street, and the party walls make an initial disruption in the formal clarity of the plan-as-ornament. Two additional rectilinear, almost within square, (18 to 20 inches) geometric containers of energy are developed concentric to and within the primary container, the building enclosure. The secondary container is the main banking room. It corresponds to the space defined by the walls of the farmers exchange, women's banking room, savings department teller's enclosure and bank officer's desks.

The tertiary container, within the main banking room is the space defined by the art-glass skylight. It defines the center of the main banking room and can be considered to be the efflorescent burst occurring when the vertical axis intersects the building envelope.

The Primary (orthogonal) axis center on the sixty-eight-foot exterior dimension. Major architectural elements are located at the points of intersection between the axis and the primary, secondary, and tertiary geometric containers. The burst of efflorescence that occurs at the site of an axial rupture of, what in Plate 4 of "A System," Sullivan called a container of energy is developed as four 
great arches. The arches falling on the intersection between the horizontal and vertical axis at the party walls contain murals, while those falling on the intersection between the axis and street-fronting walls contain art-glass windows. The walls of the primary enclosure are recessed slightly within a larger edge frame, separating one wall from the other. The arches are further developed with an additional stepped chamfer, which magnifies the architectural presence of the arch in the wall.

Where primary axis ruptures the secondary enclosure, the perimeter of the main banking space, with organic energy growing from the center outward, efflorescent bursts can be found in the form of the heavily ornamented tellers' wickets and vault enclosure and as the heavily ornamented entry portal.

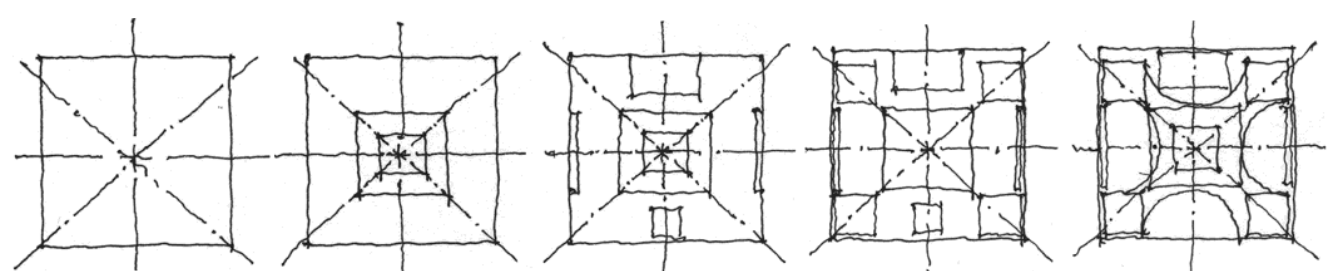

Figure 14. Development of Farmers and Merchants Bank Floorplan according to Axis/Container Method used by Sullivan in "A System"

Source: Author.

In this, most of his other buildings, the diagonal axis plays a secondary role organizing functions, not quite as important as those falling on primary axis, vault, main banking space, and entry, but more important than those occurring in the annex and basement level. In this bank, those functions falling at the street-front adjacent to the entrance are almost square in form. The functions falling on the diagonals may be indicators of stage of developmental accomplishment and problems faced by Sullivan (or Elmlie) as they continued the development of building as ornament. In the National Farmers Bank, the pragmatics of spatial function are seldom sacrificed by the architects in favor of achieving formal clarity. A notable exception to the prosaic role of the diagonal axis in this building can be found where the diagonal intersects the square skylight. At the site where the diagonal axis intersects the tertiary container of energy described by the skylight, four cast-iron electroliers burst down from the ceiling plane. A wisp of plater ornament is found at the site of each electrolier's penetration of the ceiling, a clear indication that the architect's considered the building's fabric to be filled with organic energy, waiting to burst forth.

In Plate 1 of "A System," (Figure 13) Sullivan begins with the container of energy, develops a trellis made from orthogonal and diagonal axis, then plants the seed germ. If the sixty-eight-foot square planform is the container of energy, and if the seed is planted in the plan center, where is the seed germ in section? 


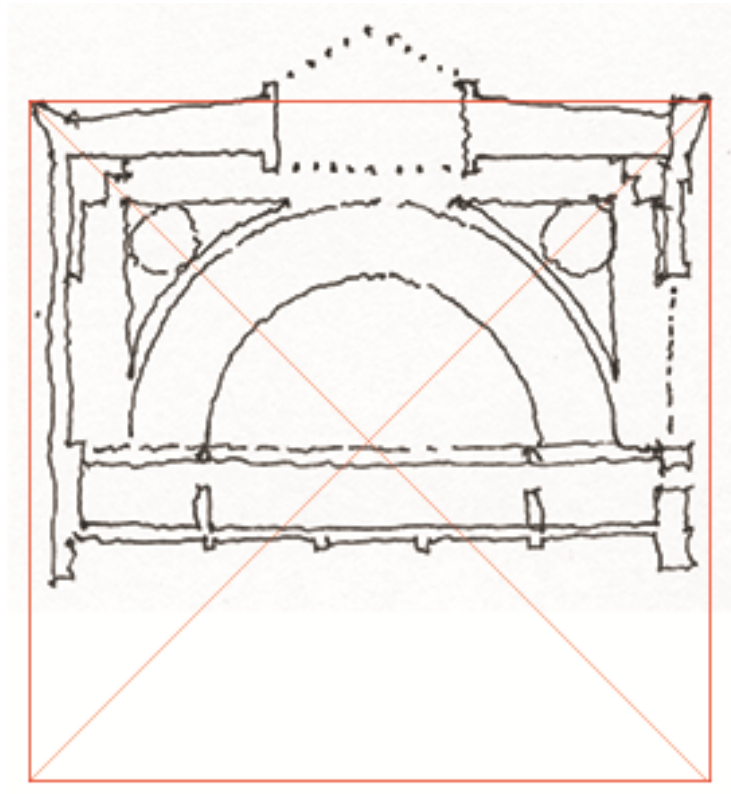

Figure 15. Farmers and Merchants Bank Section Showing the Center (Seed Germ) Located at the Horizon between the Pragmatic (Lower) Banking Functions and the Ideal (Upper) Ornamented Volume

Source: Author.

The bank is forty-nine feet high overall, if we draw a square, aligned with the cornice top, we find the horizontal centerline of the square falls precisely at the top of the green terra-cotta band that is the cornice for the president's office and the upward limit, the horizon, for all of the banking floor functions, and the is the elevation where Sullivan, or more likely Elmslie planted the seed germ (Figure 15). This horizon recognized the formal rules of the sixty-eight-foot square plan, but not the essential act of the bank, the transaction, the moment when the customers trust was extended to the teller by passing their hard-earned money to the teller across the countertop deal plate.

Case \#2: Peoples Savings Bank, Cedar Rapids, Iowa, 1911

The building is a rectangle 90 feet long and 56 feet wide. It appears that the program required filling most of the available lot length and width, perhaps an initial limitation of Sullivan's choices for the formal clarity of the perimeter geometry.

This ungainly 1:1.6 site-driven building footprint may have provoked Sullivan's development of the geometric containers from center to perimeter, rather than the perimeter to center approach used at the Farmers and Merchants Bank in Owatonna. This difference of approach was detected after numerous attempts to construct diagonals, squares, collections of squares from the perimeter rectangle and find consequential alignments with edges of spaces, major architectural elements, and major functional elements.

The primary elements of this building are its distinctive four chimney-pier elements and setback clerestory mass. In the plan, the chimney-piers carry through 
the main banking floor and define the corners of the main banking space. The vault falls on the center axis between the chimney piers and the entry portal falls on the opposite end of the axis. Three ornamented light fixtures also fall on the central axis (Figure 16).

The concentric rectangular spaces defined by the inside and outside edges of the masonry chimney-piers (as is the case with Frank Lloyd Wright's use of masonry piers) are considered the primary and secondary geometric containers respectively. This conclusion is supported by the correspondence of the setback mass of the art-glass clerestory above. Given this, the location of the vault and entry portal can be considered as efflorescent bursts occurring where the axis ruptures the primary and secondary geometric containers.

Three ornamented columns fall on either side of the central axis making four equal spaces between the chimney-piers. Two additional columns fall just inside the entry portal and support an ornamented drop beam that traces the ceiling line of the higher art-glass clerestory above. Three ornamented light fixtures fall on these column lines where they cross the central axis.

The chimney piers themselves are efflorescent bursts from the rupture of the innermost geometric container by the diagonal axis. while the rupture of the secondary geometric container falling at the back-face of the piers produces the square spaces on either side of the vault, the safety deposit desks and the bookvault/stair. At the building front, flanking the entry portal, the square-space efflorescent bursts are the men's and women's exchange spaces.
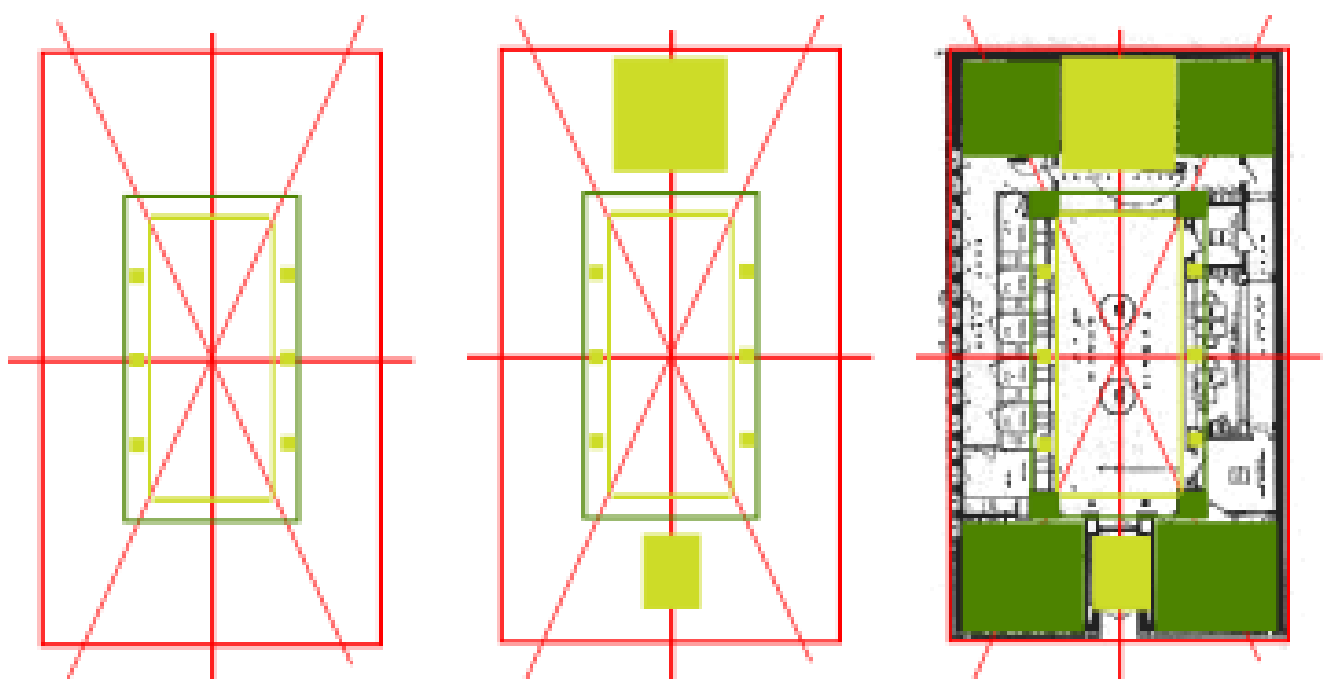

Figure 16. Peoples Savings Bank, Developed according to the Axis/Container Approach Used by Sullivan in Plate 1 of "A System" Source: Author.

Because most of the main floor architectural elements fall upon or are located in response to the central axis, vault, lights, check stands, entry portal, column and chimney-piers, this main floor plan is more strongly related to the root-stem-bloom ornament (frontal view of the primal flower/Urpflanze) type. In this formulation, the root is identified with the men's and women's exchange rooms, the stem with the entry portal, columns, light fixtures and clerestory, and the bloom with the 
vault. These correspondences of elements to axis, do not explain the exterior massing decisions made by Sullivan. The extreme verticality of the chimney-piers and visually clumsy proportion between the setback art-glass clerestory and the habitable base of the bank are not explained by the root-stem-bloom axis.

An extended speculation would be that this root-stem-bloom structure is simply the base layer, the operational/pragmatic layer and that the four corner piers are so strongly stated with the setback clerestory because this upper, uninhabitable space is an additional layer. If true it would be, similar to the upper portion of the Farmers and Merchants Bank, a more ideal zone where the formal clarity of the elements is unimpeded by pragmatic functions. If this is the case, these small bank commissions would have a stronger link to the lineage of the Schlesinger - Meyer and Gage Building with their root-bound flower pots as the first floors, and their foliage developing unhindered on their steel trellises. The center, the place where the seed germ is planted in Plate 1 of "A System," of a square between the corners of the chimney piers, aligned with the top of the ceiling falls at the base of the teller wicket, at countertop height. (Figure 17) The distinction between this bank at Cedar Rapids and the Bank at Owatonna is that the height where the seed germ is planted at Cedar Rapids falls precisely at the height of the deal plate, the countertop where the exchange between the customer and teller takes place. A functional center, not a formal center.

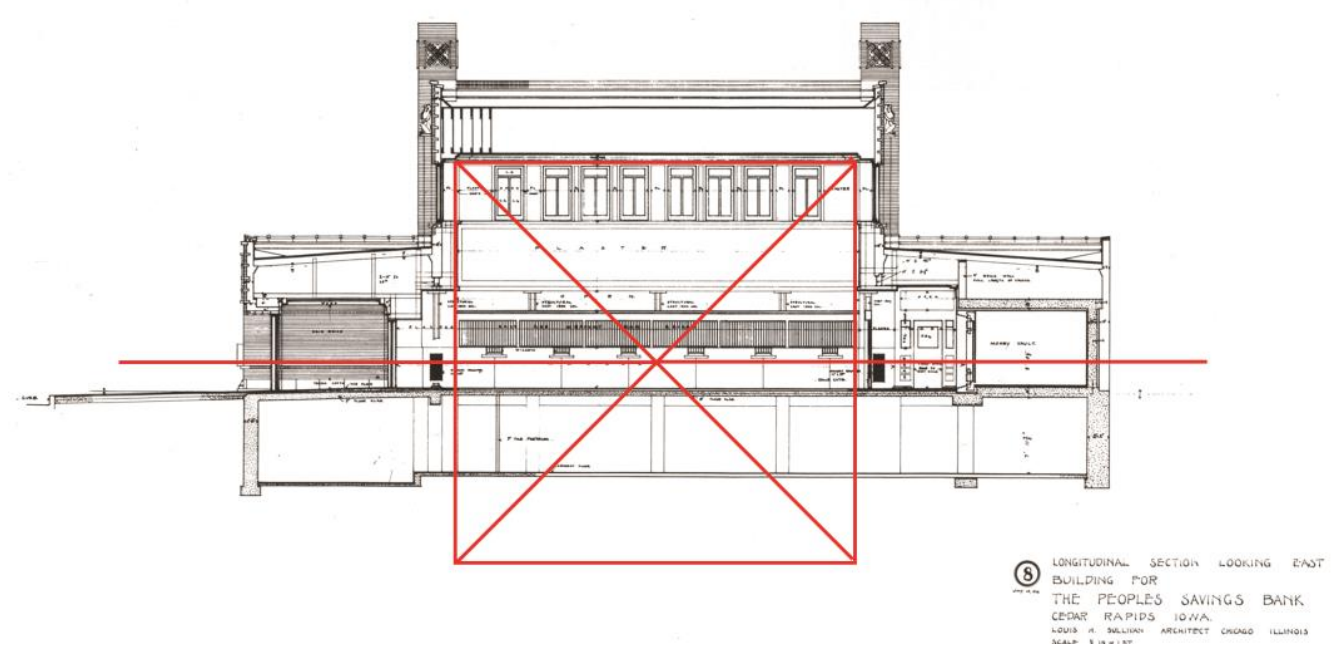

Figure 17. Section through Peoples Savings Bank, Showing Square Geometry Bound by Inner Faces of Piers and Ceiling, and Center Falling on the "Deal Plate" or Place of Exchange with the Bank Tellers

Source: Author's diagram overlay on the Peoples Savings Bank Section presented in People's Savings Bank in Cedar Rapids, Iowa, by Louis Sullivan - 1911, as retrieved from: http://pc.blog spot.com/2017/01/peoples-savings-bank-in-cedar-rapids.html.

Case \#3: The Merchants National Bank (1914)

This building is approximately 40 feet wide at main facade by 72 feet long by 35 feet tall. The public banking space between tellers is 15 feet wide by 34 feet 
long by 24 feet tall. From basement floor to roof is almost 44 feet. The skylight itself is 45 feet long and 13 feet wide

The Merchants National Bank in Grinnell, Iowa is similar to the Farmers and Merchants Bank in Owatonna, and the Peoples Savings Bank in Cedar Rapids in that it is a one-story-plus-basement building. Like these other banks, the Merchants National Banks main banking space is a double height space. As one enters the space, the main architectural elements are the ornamented cornice flanked by two piers with terra-cotta planters at the safe deposit teller and vault, the art-glass skylight, the art-glass window on the right side and six suspended electric lightoliers, three on each side of the skylight. Within the public banking space, the circular window over the entry portal, the clock in an ornamental ceramic surround, and the projecting entry portal itself are the major architectural elements.
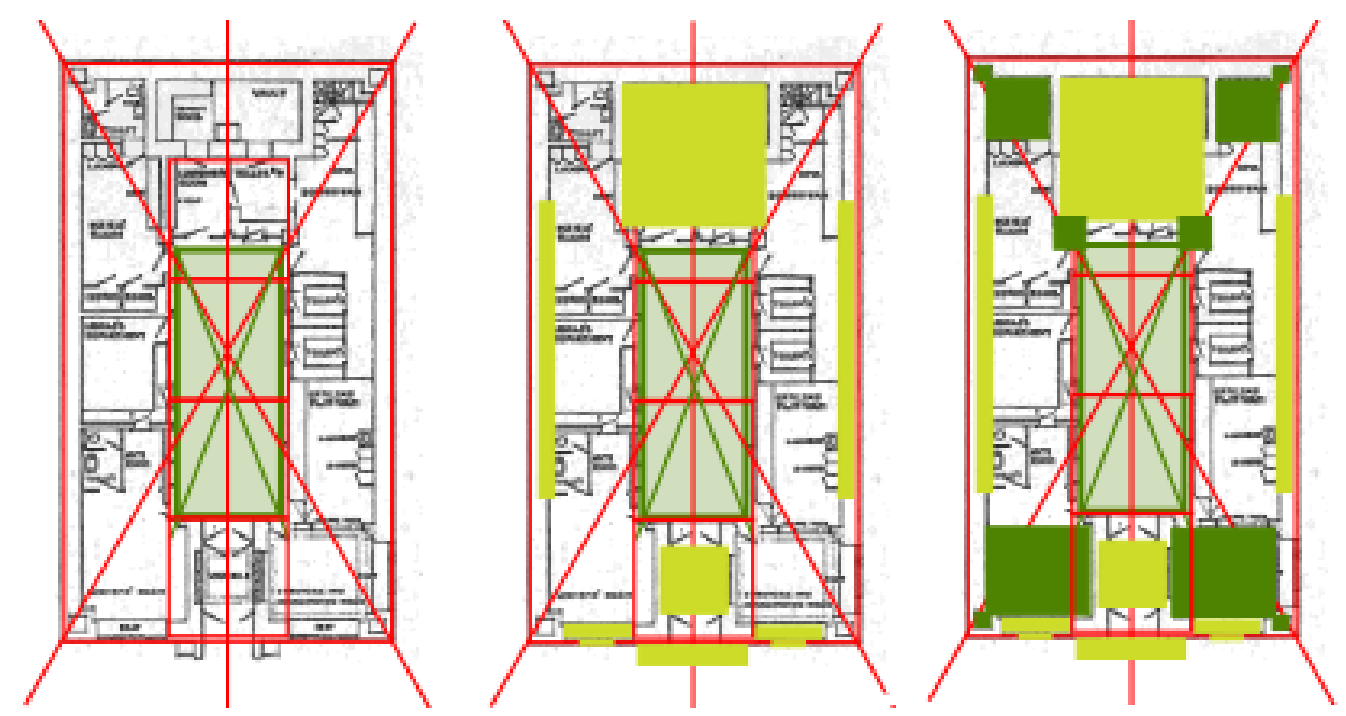

Figure 18. Peoples Savings Bank, Developed according to the Axis/Container Approach Used by Sullivan in Plate 1 of "A System"

Source: Author's diagram overlay on the Peoples Savings Bank Plan presented in the authors copy of the western architect v.23 1916.

Like the Peoples Savings Bank, major architectural elements are arranged along the long axis extending from the entry portal to the vault. The cross axis is only presented by the art-glass windows facing the side street. The piers with terracotta planters flanking the ornamented vault cornice reinforce the termination of the public banking space. One can see the structure of this axis and termination being a root-stem-bloom form-type with the entry portal again playing the role of the efflorescent burst as root, the public banking space articulated by both the artglass skylight and the six suspended lightoliers as the stem, and the ornamented cornice-pier combination as the efflorescent burst at the end of the interior axis as the bloom. Where this axis punctures the perimeter, the exterior entry ornament stands as a major deposit of efflorescence on the surface of the exterior container of energy. The diagonal axis holds four corner spaces that are secondary or supporting spaces to banking activity. The upper left diagonal efflorescence is a toilet. The upper right is a stair from the bookkeeper's space to the basement, the 
lower left diagonal efflorescence is the women's room, and the lower right diagonal efflorescence is the directors and consulting room (Figure 18).

All three of these case study banks considered to this point both make strong distinctions between what has been called the "zone of the pragmatic" where people inhabit the space and what has been called the "zone of the ideal," located above this inhabited functional space populated with architectural elements such as light fixtures, skylights, and murals all located according to Sullivan's principles as described in Plate 1 of "A System" The Merchants National Bank (1914) is different in that the distinction between the upper and lower zone is not readily apparent on the exterior. Unlike the bank in Cedar Rapids, that makes the distinction with a significant massing articulation, or the bank in Owatonna that makes the distinction with a color, texture, scale, and material change, The Merchants National Bank only distinguishes the upper from the lower zone with the window head at the director's office and the window sill of the art glass window facing the side street. Because of this one could consider the design more unified than the previous examples.

Were it not for the strong articulation of an interior cornice at approximately nine feet above the banking floor one could assert Sullivan is making a new proposition about the whole-ness of the Merchants National Bank. Testing the section to find the height of the seed-germ above the floor one finds there is no corresponding square aligning with the ceiling height as there was in the Cedar Rapids bank. The extreme length of the skylight seems to disrupt the interior ordering of both the formal logic of the section and insofar as the skylight corners extend one panel beyond the location of the lightoliers, it disrupts the formal structure of the zone of the ideal as well.

The two squares that can be made in the section between the edges of the underside of the art-glass and the surface of the floor overlap an equal amount as the two larger squares that can be drawn by extending forty-five-degree diagonals from the building enclosure towards the center. That these squares below the skylight appear to have no other architectural consequence makes them insignificant at best, and at worst they weaken the formal structure of the whole.

Forty-five-degree diagonal lines extended from the corners of the building perimeter align with the corners of the skylight. Extended to the perimeter wall, these diagonals intersect at the centerline of the overall building perimeter. If the suspended lightoliers had fallen at the corners of the art-glass skylight, they might have been considered efflorescent bursts of the seed germ growing from the center of the skylight along the diagonal axis of the skylight. As the six lightoliers fall slightly within the length of the skylight they must be considered either markers of another structure, or more likely indicators of the pragmatic necessity to distribute electric light equally across the banking room. If this is the case, it would stand as a corruption of the zone of the ideal and as such, might serve to further strengthen the assertion by Morrison, Andrews and Jordy who cite a reduction of Sullivan's powers during this time period. 


\section{Results}

These observations on Sullivan's medallion-type of ornament revealed a partial set of the strategies being used to infuse inert material with an irrepressible life-force. ${ }^{28}$ The role of analytical representations of botanical anatomy by Gray has shown that "plan" "section" and "elevation" were not terms simply reserved for design and construction of buildings, but could be applied to living organisms in order to better understand the complex inner workings of things we know primarily by their exterior appearance. The incorporation of geometrical forms and gridlines into Sullivan's terra-cotta herbarium gave, or was, a set of miniatures that allowed him to develop the relationship between the rational means of building and the celebration of the energy expended in service of a larger enterprise by the people within. These low-risk experiments began to expand in scale in the Wainwright and Guaranty buildings as expressions of vertical growth and internal vitality, not as expressions of the skeletal means of construction. The tall buildings designed by Sullivan were simply planters with a cage of vertical, horizontal and diagonal trellis supports within.

But ultimately, how important was it that the buildings conform to the formal methods used by Sullivan to develop ornament? Did the buildings have to meet the rule with a level of precision that may have compromised convenient use of the bank?

These three brief studies of the Farmers and Merchants Bank, the Peoples Savings Bank, and the Merchants National Bank have provided the opportunity to speculate that Sullivan was indeed following the principles for ornament described in "A System" when he designing the plan and section for these buildings. These studies have also made it possible to speculate, that like the burst of efflorescence at the entrance to the Merchants National Bank, Sullivan may have been working with the principle of layers as found in the ornament. A mediating layer in plan or section made up the difference between dimensional needs for specialized activity or the limitations imposed by lot proportion and more idealized proportions for the "containers of energy" that were typically arranged as concentric forms originating in the public banking space. These mediation layers seem to be always separated vertically from an upper zone of the section by a defined interior cornice line or horizon that was frequently emphasized on the buildings' exterior with massing or material changes or the alignment of window heads and sills. In this way the whole of the public banking floor could be considered, in section, to be a mediating element of the ornament whose purpose is to meet the program and prepare the ground for the seed-germ. The horizon where the seed germ was planted seems to vary, and this may be the key weakness of the "building-asornament" proposition.

It seems clear that Sullivan (or equally likely, Elmslie) distinguished between the lower and upper space in the Farmers and Merchants Bank on the basis of the formal geometric aspects of the building. (68-foot square plan, 34-foot upper zone,

28. L. Sullivan and I. Athey, Kindergarten Chats (Revised 1918) and Other Writings (New York: Wittenborn, Schultz, 1947), 206-208.

29. Ibid, 208. 
half the cube) It also seems clear that at the Peoples Savings Bank, Sullivan positioned the interior horizon at the deal plate - plane of exchange between teller and customer, but the exterior massing suggests the upper zone only encompasses the clerestory. In both these banks, the presence of the murals, idealized representations of the countryside and the values promoted by the banks (orderliness, industriousness, tranquility) and the relatively few functional expectations for the upper zone supports the speculation that these upper portions of the space were the place of the ideal, while the banking spaces below the horizon of the interior cornice lines were places for more pragmatic concerns. The combination of these two zones as an integrated whole would seem to epitomize Sullivan's declared ultimate goal of architecture, the fusion of opposites through the interplay of organic and inorganic elements.

It seems clear that as long as Sullivan could consider the building envelope and the perimeter of the public space as inorganic containers of energy, and that at each axial puncture of a container a burst of vegetal ornament could be made, he could build ornament at the scale of building.

But the break with principle at the Merchants National Bank weakens this argument. It seems that had the skylight been one panel shorter at each end, the light fixtures would have taken their logical place as bursts of efflorescence at the end of the diagonal axis extending through the skylight corners. But they don't. Was this an error, compromise or was Sullivan just enjoying the ornament without the baggage of perfecting the whole?

These observations categorized the development of Sullivan's approach to expressing what he called "LIFE" 30 in the medallion-type of ornament as the spiral, energized emanations, wind-swept, the pulsar and ready-to-burst. These observations conclude with the role played by the ready-to-burst approach to the medallion-type and the root-stem-bloom form type in some of his later projects.

These three case-study projects succeed in mapping functions and architectural elements as major and minor bursts of efflorescence according to the principles of development articulated by Sullivan in Plate One of "A System." But ultimately Sullivan was unable to fully translate the organic element of his ornament to the scale of building. This and the relatively modest scale of his last commissions prevented even the full development of formal clarity in the inorganic elements when scaled-up to the building as a whole. In the struggle between the inorganic and the simply pragmatic, the pragmatic governed, often to the detriment of the clarity of the whole building scheme.

\section{Conclusions}

Still, Sullivan's efforts to "enter into communion" with and express the life within his buildings designed between 1890 and 1922 remain as critical examples of, as Sprague describes, an architecture both rational and vital. ${ }^{31}$ His work remains as the prototype of "building-as-organism" that underpinned the most

30. Sullivan, The Autobiography of an Idea, 1956, 235.

31. Sprague, The Architectural Ornament of Louis Sullivan and his Chief Draftsmen, 1969, 5-8. 
significant revolution in space and form in American Architecture to date, the Prairie Houses of Frank Lloyd Wright. ${ }^{32}$

\section{Bibliography}

Beeby, T. H. "The Grammar of Ornament/Ornament as Grammar." In Ornament. Edited by Stephen Kieran. Philadelphia: Graduate School of Fine Arts, University of Pennsylvania, 1977.

Dupree, A. H. Asa Gray 1810-1888. Cambridge, MA: Harvard University Press, 1959.

Durand, J.-N.-L. and J.-N.-L. Durand. Précis of the Lectures on Architecture, with, Graphic Portion of the Lectures on Architecture. Translated by David Britt. Getty Research Institute, 2000.

Gray, A. and A. Gray. Gray's School and Field Book of Botany: Consisting of "Lessons in Botany," and "Field, Forest and Garden Botany." New York: Ivison, Blakeman, Taylor \& Co., 1874.

Hawkins, J. and S. Le Roux. The Oxford Reference Dictionary. Clarendon Press, 1986.

Jordy, W. American Buildings and their Architects: Progressive and Academic Ideals at the Turn of the Twentieth Century. New York: Anchor Books, 1972.

Millett, L. Curve of the Arch: The Story of Louis Sullivan's Owatonna Bank. St. Paul, MN: Minnesota Historical Society Press, 1985.

O'Brien, M. "After the Starchitect.” Athens Journal of Architecture 5, no. 3 (2019): 301318.

. "Learning from Lost Wages: The Necessity of Design Research...A Historical Account of Frank Lloyd Wright's Search for Voice." ARCC 2019 Poster.

Olin, M. R. Forms of Representation in Alois Riegl's Theory of Art. Penn State University Press, 1992.

Riegl, A. The Problems of Style: Foundations for a History of Ornament. Edited by David Castriota. Princeton, NJ: Princeton University Press, 1993.

Sprague, P. E. The Architectural Ornament of Louis Sullivan and his Chief Draftsmen. Doctoral Dissertation. Princeton, NJ: Princeton University, 1969.

Sullivan, L. A System of Architectural Ornament according with a Philosophy of Man's Powers. Press of the American Institute of Architects, inc, 1924. The Autobiography of an Idea. New York: Dover Publications, 1956. . A System of Architectural Ornament according with a Philosophy of Man's Powers. New York: Eakins Press, 1967.

Sullivan, L. and I. Athey. Kindergarten Chats (Revised 1918) and Other Writings. New York: Wittenborn, Schultz, 1947.

von Goethe, J. W. Versuch die Metamorphose der Pflanzen zu Erklären [Attempt to Explain the Metamorphosis of the Plants.] Gotha: Ettinger, 1790.

Wilson, E. The Cell in Development and Heredity. New York: MacMillen Company, 1896.

32. O’Brien, "Learning from Lost Wages: The Necessity of Design Research...A Historical Account of Frank Lloyd Wright's Search for Voice," ARCC 2019 Poster. 